\title{
Business Model Innovation Approach for Commercializing Smart Grid Systems
}

\author{
Harrison John Bhatti', Mike Danilovic ${ }^{1,2}$ \\ ${ }^{1}$ Halmstad University, School of Business, Engineering and Science, Halmstad, Sweden \\ ${ }^{2}$ Shanghai Dianji University, Shanghai, China \\ Email: harrisonjohn03@gmail.com,mike.danilovic@hh.se
}

How to cite this paper: Bhatti, H.J. and Danilovic, M. (2018) Business Model Innovation Approach for Commercializing Smart Grid Systems. American Journal of Industrial and Business Management, 8, 2007-2051.

https://doi.org/10.4236/ajibm.2018.89134

Received: August 28, 2018

Accepted: September 27, 2018

Published: September 30, 2018

Copyright $\odot 2018$ by authors and Scientific Research Publishing Inc. This work is licensed under the Creative Commons Attribution International License (CC BY 4.0). http://creativecommons.org/licenses/by/4.0/

\section{Abstract}

The depletion of fossil fuels, increased environmental concerns, rising cost and the demand for clean energy are causing the transformation of energy generation and distribution system, to shift towards the consumption side. Electricity generation sources and distribution systems are drifting from non-renewable to renewable, centralized to decentralized and localized, and traditional grid systems to smart grid systems. New technologies nurture the concept of transformation of energy firms, all the way from energy production to electricity consumption. Smart grid systems are one of the disruptive and emerging technologies that might influence the entire electricity system. This disruptive technology demands a new business model which can be used to commercialize the new power distribution system and thus create value for all stakeholders, from production to consumption. The Smart grid has the potential to revolutionize the electricity industry if it is commercialized successfully. It allows information and communication technology firms to contribute with their modern technology to empower their consumers to regulate the usage of electricity. To investigate the reasons for shifting from the old to the new energy system, the impact of this disruptive technology on energy providing firms, the demand for the new business model and the approach of the new business model in terms of creating and capturing values published peer-reviewed articles, and international energy agency reports have been reviewed. This paper encourages energy providing firms to redesign business models for commercializing new energy distribution system and to offer new services to the energy consumers for their future survival in the new trends of the energy market. These services include integrating with renewable energy sources, electric vehicle services, and demand response services to create more value for the consumers and in return gains more profit for each actor. The services provided through integration of renewable energy with smart grid and the electric vehicle will empower consumers involvement in the 
electricity system which will give them more control over electricity. $\mathrm{CO}_{2}$ production will be reduced, helping to create a clean environment and will enable operators to improve grid security and network stability. Finally, demand response services will provide multiple electricity package options to the consumers in which they can select an appropriate package according to their need which will give them more control over their electricity bill. System operators can optimize their grid operations to provide better power quality, and service providers can increase their income by offering additional services.

\section{Keywords}

Smart Grids, Electricity Firms, Business Models, Disruptive Technology, Sustainable Energy

\section{Introduction}

In this modern era, on the one hand, the demand for electricity is increasing while on the other hand, fossil fuels are depleting which are used for power generation. Therefore, Bhatti et al. [1] and Grace [2] stated that one of the reasons for high-cost electricity delivery and inflexibility is the dependence on a centralized system of power generation and old technology in energy distribution systems. The centralized power generation system mainly relies on non-renewable energy sources to produce electricity. The installation, transmission, and distribution of electricity with a centralized system are costly in distant areas and cannot handle the increased variation of energy sources and new consumption patterns among consumers. Fossil fuels are one of the causes of harmful gas pollution which negatively effects peoples' health and the local climate. Therefore, a different method for electricity generation and delivery is necessary to face these challenges. According to Allen et al. [3], traditional energy market economics have been moving towards decentralized energy systems. For instance, residential level solar photovoltaic and storage is used, and on a community level there are numerous ongoing sizeable projects of renewable energy. These trends are creating "risks" for traditional energy system, and energy companies are already making strategies for further investment in the industry of renewable energy. McDonough et al. [4] stated that all these components of energy system evolution create new and better ways of electricity generation and distribution. Making smaller systems and industry may be a new way of electricity supply since effectiveness will be higher. For making the new systems, redesigning is needed, which can make systems recharge and maintain themselves.

A decentralized system of electricity is based on handling localized renewable energy sources which provide clean and eco-friendly energy. The decentralized system is an alternative option to reach the rising demand for electricity in distant regions. Therefore, electricity delivery problem in village regions can be 
solved by integrating localized renewable energy sources with the decentralized and intelligent power distribution system (smart grid), which is capable of managing variations in energy sourcing and energy consumption. In the world, the adoption ratio of decentralized electricity generation systems was $13 \%$ in 2001 , and it increased by $12 \%$ within four years, reaching $25 \%$ at the end of 2005 , and a year after in 2006, it reached $36 \%$. Based on the benefits of decentralized electricity generation systems, more growth is expected in the future. Calculations show that by 2030 , the cost of electricity generation may reduce to $\$ 2.7$ trillion, due to the efficient integration of renewable energy sources with intelligent, decentralized electricity generation systems and energy distributed through a digitalized smart grid system [1].

According to Christensen [5], the term "disruptive technology" refers to new products or services which transform markets and businesses. Disruptive technologies bring changes in market structure and in value delivery. Usually, the concept of "disruptive innovation" is used as an alternative phrase for "disruptive technology". Furthermore, the business model enables the impact of disruptive technology. Bower et al. [6] defined and made widespread the concepts of "disruptive technologies" and "disruptive innovations". The center of economic innovation is innovation in technology. New knowledge, products, and services create the resources for better life quality, value creation and problem-solving. Due to innovation, technologies are continuously evolving. According to Bower and Christensen [6], technologies which cause structural changes in the market, as well as affect market-leading organizations, are called disruptive. During the market entry, disruptive technologies have limited effect. However, after a short period, disruptive technologies are entirely changing existing technologies. Unlike dominant technologies, disruptive technologies are straightforward, low-priced and more reliable. Nevertheless, consumers do not care about some characteristics of disruptive technologies [5]. Disruptive innovation has been noticed in the energy industry in the last decade. Power generation sources and the distribution system have been the focus of innovation as to mitigate the rising demand for electricity. The distribution structure and the transmission part of the energy sector remained untouched [7].

In this age, the smart grid is an emerging technology in the energy industry, and it has the potential to revolutionize, integrate and enable all the different parts of the energy value chain to function [8]. Inage [9] explains that the smart grid is an electricity network. It uses advanced, innovative and digitalized technology to manage and monitor the distribution and generation of electricity from different sources to fulfill the demand of consumers. Therefore, the question arises, how can grids be made smarter? The answer is, by intervening in information and communication technology, because information and communication technology (ICT) has the potential to embrace distributed energy, enhancing and corresponding with the electricity network and offers control over sustainability and energy savings. The goal of smart electric grids is to provide sustainable, reliable, safe, as well as in expensive electricity to consumers. Fur- 
thermore, a smart grid allows their consumers to generate electricity for themselves by using distributed and renewable sources. A smart grid enables its customers to have control over the consumption of power in their own homes [10].

The existing centralized generation and distribution of electricity systems are associated with traditional business models [11]. Researchers of utility business models find that the expansion of renewable energy systems creates a severe challenge for present utility business models [12]. According to [13], business models are framing the layout on how a firm makes, conveys and captures value. The nature of the business model is to describe a way about how firms bring value to customers, make them pay for it and transform the payments into profit [14]. According to DaSilva et al. [15], the critical point of a business model is to find a unique combination between a firms' resources and capabilities, and discover an efficient way of utilizing it to create value for the firm and its customers.

When the new technology appears, managers could use business models to see how they could gain profit from executing the technique. Thus, several scholars see business models as a middle point between technological innovation and value creation [16]. Outside-of-industry investors are entering the electric power sector by purchasing more and more shares, which is making utilities have less shares. Thus, the primary challenge of electric utilities is to find better ways of commercializing the technologies of renewable energy. Researchers have determined that established energy firms have problems with changing their business models. The companies are getting profits by using their current business models, but in the future, the situation could change due to technological development or environmental changes [17]. In many cases, new technologies are not fully applicable to the current market, and they are different from companies' business models [18]. According to Christensen and Bower [18], many companies are losing profits to theirs competition not because of new technology, but because they are failing to change their current business model and implement new business models with new technologies.

This paper is divided into three main sections: 1) Energy transformation; 2) Disruptive technology and 3) Business model.

\subsection{Problem Statement}

In recent years, the advancement in information and communication technology (ICT) and the involvement of ICT firms in the electricity industry have brought tremendous disruption. The concept of a centralized power generation system with the usage of fossil fuels is rapidly shifting towards decentralized and localized power generation systems with the utilization of renewable energy sources such as; wind, solar PV, hydro and biogas. Similarly, the distribution of power generation system is moving from traditional grid systems to smart grid systems. This emerging change in the electricity industry can meet the future demand for electricity and provide clean energy at a low price and flexible solutions to the consumers [1].

However, this disruption in the electricity industry has a direct impact on the business models of energy providing firms. The main problem is that energy 
providing firms are hesitant to change their established business models. They want to commercialize the new system (Smart grid) of electricity with their old business model based on the assumption that the entire value chain remains as it is. However, the smart grid system enables the integration of energy sources and energy consumption in different ways and different combinations, demanding the dynamics of the value chain and thus demanding for a new business model, enabling the creation of new value to consumers.

Therefore, Bocken et al. [19] stated that although electricity firms are strategically trying to rebuild themselves towards sustainable energy, they are still experiencing uncertainty about business model design, which will be both profitable and sustainable. Mah et al. [20] insisted that many smart grid technologies are ready for use, but electricity firms are still failing to generate profits from them because they want to commercialize disruptive technology with the old business model. Shomali et al. [21] stated that ICT firms have a high impact on smart grid when smart grid is introduced in the market, the utility providing firms need to upgrade their business model regarding capturing profit from third parties. Furthermore, as per Amit et al. [22], utility providing firms have incentives for updating their business models to integrate smart grids and include solar PV and storage as well. However, for incumbents, there are several challenges, such as the market entrance of new players, uncertainties with government support, enrollment of customers, as well as an unwillingness for business model innovation caused by a fear of losing streams of revenue.

Thus, Sosna et al. [17] stated that the primary challenge for electric utilities is to find better ways of commercializing the technologies of renewable energy. Researchers have determined that established firms have problems with changing their business models. The companies are getting profits by using their current business models, but in the future, the situation could change due to technological development or environment changes. Finally, Christensen and Bower [18] clarify that many companies are losing profits to their competition not because of new technology, but because they are failing to change their current model and implement new business models with new technologies.

\subsection{Purpose of the Research}

This study explores the impact of disruptive technology (intelligent and decentralized smart grid systems) on energy providing and energy distribution firms. Further exploration is focusing on the need for a new business model to commercialize the new intelligent and decentralized energy distribution grid systems in order to create, deliver and capture value for the mutual benefits of consumers of energy and renewable energy producers and energy distribution firms.

\section{Research Methodology}

This research has been conducted to explore the evolutionary impact of disruptive technology on the energy industry, reasons for shifting from the old to the 
new systems of power generation and distribution, which demands a new business model to commercialize the new system. The smart grid is a relatively new disruptive technology which is expected to transform the energy industry. Being as it is a new technology, there are no real implementation, that can be seen in real life and real business. Thus, this research is tentative in which literature has been reviewed and indicative of a possible future revolution in the energy industry.

In order to perform the research three databases were mainly focused on in the literature review. ABI/Inform Global is one of the wide-ranging databases that cover broad areas of research, such as; business, corporate strategies, economic conditions, management techniques and business trends. Furthermore, not only are peer-reviewed articles or other databases just indexed, but it provides the full text. Emeralds journal also covers broad areas of research. It has been categorized into sub-fields, such as; accounting, finance and economics, business, management and strategy, education, engineering, health, social care, library studies, and marketing. It provides holistic research sources to the researcher. Science Direct which is operated by Elsevier covers engineering and business peer-reviewed articles. Furthermore, international energy agency (IEA) reports published by the French government have been considered to get a deeper understanding of the involvement of different governments in the energy industry.

To identify the relevant articles, the search has been divided into two segments. The first search is based on disruptive technology in general and energy in particular, and its impact on business models for commercialization of energy providing and distribution firms. The second search is related to the business model innovation approach for commercializing a smart grid system. The selection of the keywords was: "disruptive technology" AND "smart grid", "disruptive innovation" AND "smart grid", "business model" AND "smart grid", "impact of smart grid" AND "business model", "business model innovation" AND "commercializing smart grid". The keywords were used in the form of phrases and were quoted with quotation marks. To refine the search "AND" operator has been used in the middle of the phrases in the advanced search bar.

The selection of peer-reviewed articles and reports has been an iterative process, screening, and filtering which is divided into three steps. In the first step, only titles of all the articles were screened, and articles with irrelevant titles were removed. In the second step, the abstracts of all the remaining articles were skimmed, and duplicate and irrelevant articles were removed. In the final step, filtration was based on skimming the full-text of the remaining articles from the second iteration. Further exclusion criteria were if the articles were too technical or had no relation to a business model for smart grid or disruptive technology.

The criteria of analysis of the data and obtaining the results vary according to each section. The first section explores the transformation of the electricity system which is further divided into three sub-sections. In the sub-sections, 1) Non-renewable to renewable energy sources, the analysis is based on the availa- 
bility and cost. 2) Centralized to a decentralized system which is analyzed based on systems integration with renewable energy sources and whether or not it is environmentally friendly. 3) Traditional grid to the smart grid system, the analysis is performed on the performance of the distribution system, customer preferences and integration with renewable energy sources. The second section explores the impact of disruptive technology on business models of different industries including energy providing firms. The criteria of analysis were to examine the reasons for success and failure of those industries. The final section explores the ways of creating, delivering and capturing value by the organizations regarding commercializing smart grid systems.

\section{Transformation of Electricity System}

In the last few years, a dramatic change has been noticed in the electricity industry in many countries around the globe. The advancement of disruptive technologies for both demand side and supply side have made it possible for the electricity industry to shift from an old to a new system which is more reliable, sustainable and affordable [23]. Figure 1 represents the shift from the old to the new electricity system.

As Figure 1 shows, disruptive technologies have brought a remarkable change in the electricity industry. The concept of centralized power generation which was supported by fossil fuels is shifting to a decentralized and localized system which can easily be integrated with renewable energy sources and with the help of the smart grid system, energy can be distributed to the end consumers. This section provides reasoning on the shift of electricity from the old to the new system. The focus is on power sources, generation and distribution systems of the electricity.

\subsection{Non-Renewable to Renewable Energy}

Demand for energy is rapidly growing within developing economies. Initially, people in Europe and the US shifted to hydropower because firewood and other biomass energy supply could not meet growing energy demand. In the middle of

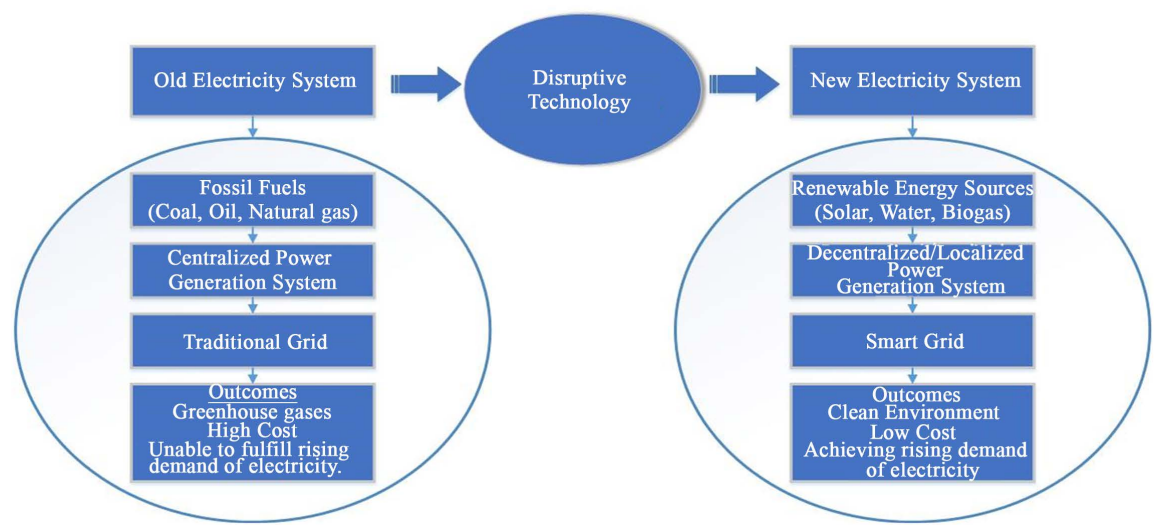

Figure 1. Transformation of electricity system (Self drawn). 
the $19^{\text {th }}$ century, people switched to coal, while in the $20^{\text {th }}$ century people shifted to natural gas and oil. In the middle of the $20^{\text {th }}$ century, nuclear power had its debut in the energy industry [24]. Every economic development era included the process of switching from one main energy source to another. Presently, the central sources of energy are fossil fuels (coal, natural gas, and oil), which are the major sources of energy generation in developing countries (see Figure 2). Nonetheless, the $21^{\text {st }}$ century is establishing a new era of energy sources by at tempting to switch energy production from fossil fuels to renewable sources. This changeover is reinforced by several aspects, such as fossil fuel delivery restrictions, costs, environmental safety (especially changes in climate and temperature) and evolution in technology [25].

Figure 2 shows that the economic infrastructure, as well as stock capital, depend on the usage of fossil fuels, as non-renewable energy sources produce $81.6 \%$ of global energy. Any changes in this situation will require substantial capital investments and severe infrastructural change. Even though private capital has the most impact on these changes, governments and authorities must adopt rules and regulations in order to legitimate and promote shifting of energy sources. The key point is renewable sources of energy, which could give numerous benefits to the economy and to the environment [24]. As non-renewable energy sources are producing electricity at the lowest cost, about $81.6 \%$ of world energy supply is provided by fossil fuels. Nevertheless, in recent years fossil fuels' advantage in costs is being reduced since many types of renewable energy can provide power at a price, which is almost similar to or even lower than fossil fuels' energy price.

Moreover, in the future, costs of renewable energy will be reduced more, while costs of fossil fuels are expected to grow. Thus, economic tendencies are going towards renewable sources, even without proper government regulations [24].

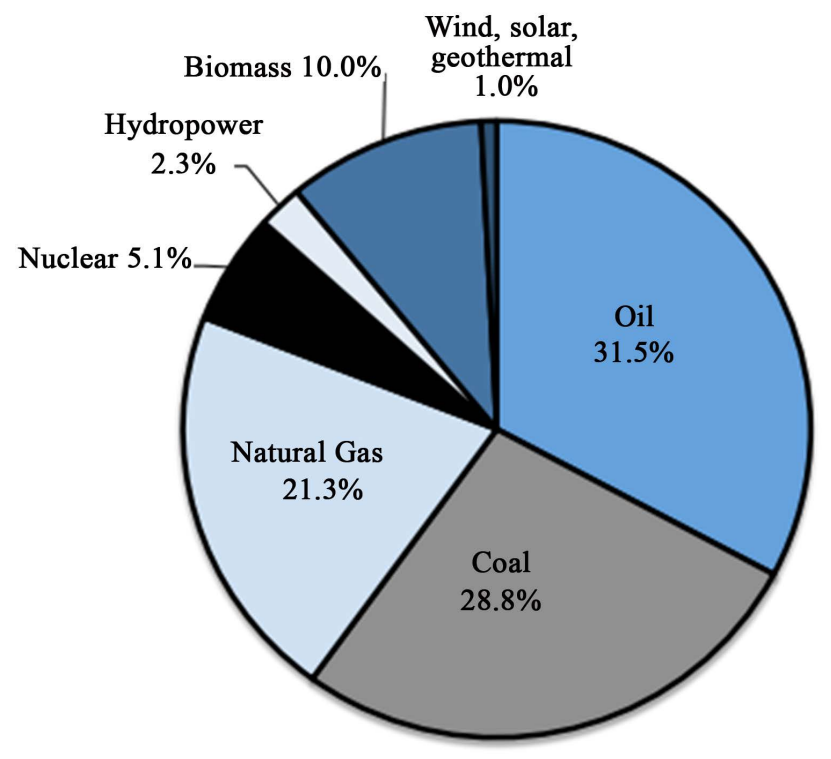

Figure 2. Global energy consumption [25]. 
Comparison of costs of various sources of energy is based on determining the levelized cost of energy (LCOE). Levelized costs show the current price required for a building or plant operation throughout the presumed time period. Real terms demonstrate LCOE to discard inflation influence. The assumption for fuel-based energy sources is built on future expected prices of fuel. Total energy cost contains operations and levelized construction prices, which makes it easier to compare costs of various sources of energy [26].

Figure 3 presents the cost comparison between fossil fuels and renewable sources of energy. Renewable energy sources need to have a similar price to power plants of fossil fuels in order to sell electricity to the grid. This price is called wholesale price of electricity. Hydropower and biomass have already reached this price. Figure 3 highlights that costs of geothermal and wind energy are almost identical to prices of fossil fuels but solar energy is expensive. However, the solar photovoltaics (PV) price requires being equal to retail power price paid by end users, because end-users of energy can easily install solar PV. The PV price exceeds the wholesale price [26].

\section{Prices and Volumes}

Past and expected price tendencies of solar and wind energy are represented in Figure 4 and Figure 5. Even though prices may reduce curve shape of price shows that prices decline slower than in the past. Furthermore, Figure 4 and Figure 5, suggest that the difference between prices of wind and photovoltaic energies will shrink. Therefore, the renewable energy costs become more foreseeable, while the situation with fossil fuels is entirely different. According to Energy report of U.S. Department, from 1998-2011 costs for U.S. PV system, every year declined 5\% - 7\%. From 2010 to 2011, PV prices declined 11\% - 14\%, and it is likely to see future decreases as well [27].

According to Timmons et al. [24], future market prices of renewable energy sources will not necessarily be lower than prices of fossil fuels, although prices of renewable energy are reducing. The net energy of renewable sources, the intensity of capital and their discontinuity are presenting main cost issues for

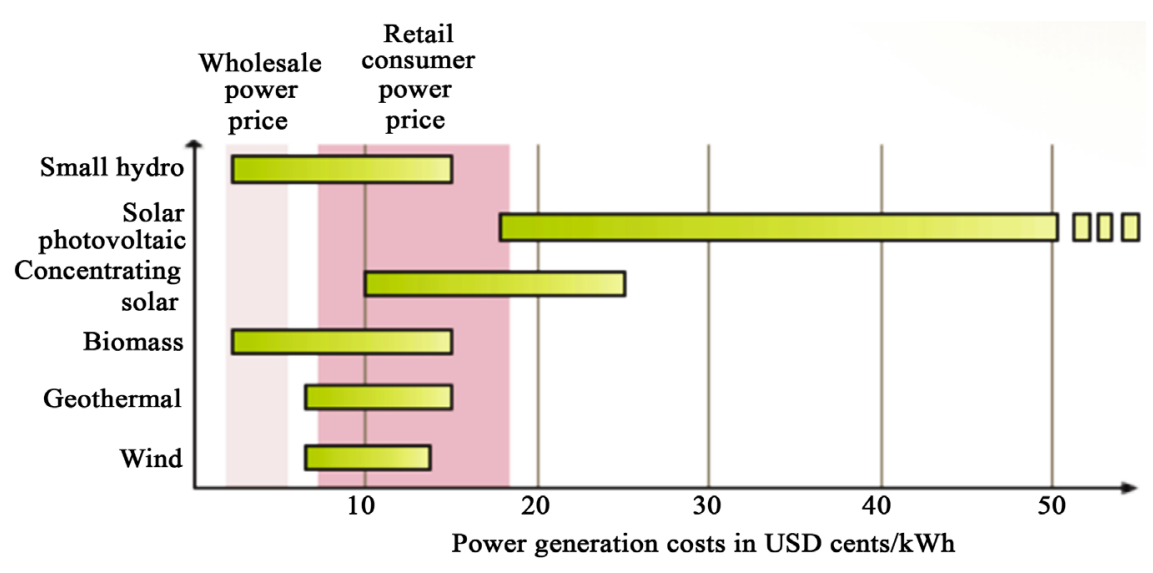

Figure 3. Cost comparison between renewable energy sources and fossil fuel [26]. 


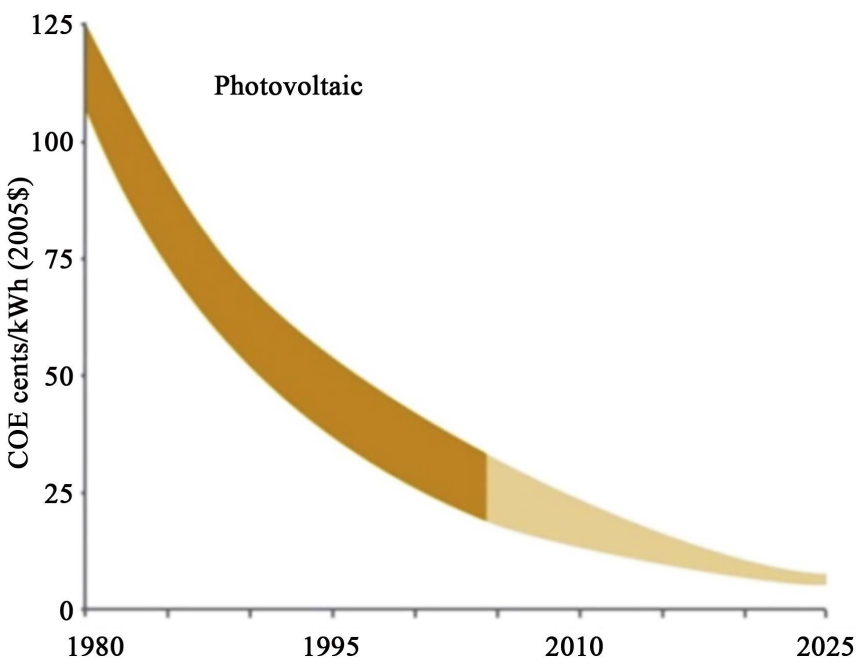

Figure 4. Declining cost of solar energy [28].

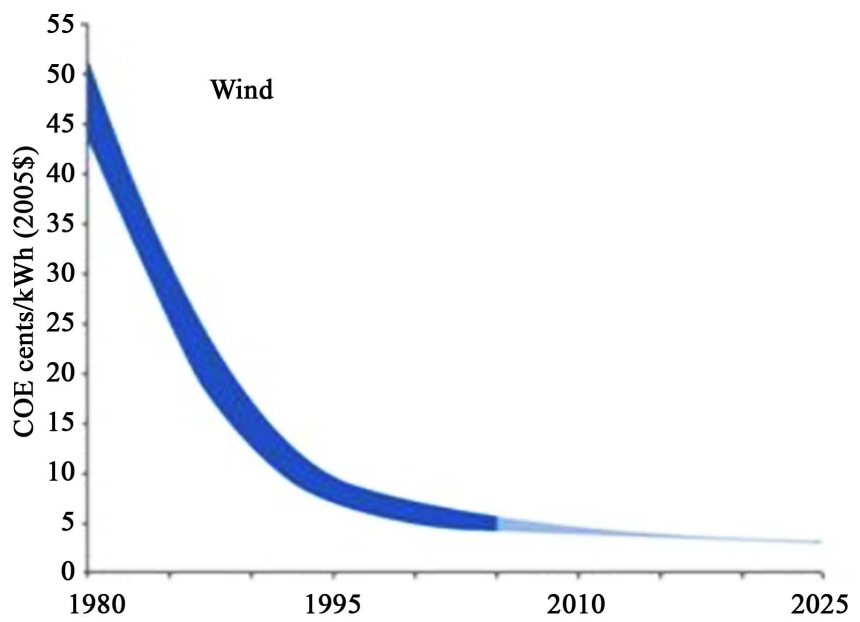

Figure 5. Declining cost of wind energy [28].

renewable energy generation. Solar and wind energy have lower operating costs because once facilities for energy production are constructed, little costis requiredin order to generate energy yearly. However, Timmons et al. [24] stated that higher capital investments are needed for building renewable energy plants, the total price of which is equal to the price of fossil fuel plant construction plus the price of purchasing all of the energy which the plant will generate for a long time. For example, fewer numbers of consumers would buy a gas furnace and all the gas which the furnace will use during its lifetime, this much money is required for implementation ofrenewable energy sources. The introduction of renewable energy sources such as solar and wind power is localized in many different locations, thus being scattered. To fully use the potential of renewable energy sources such as solar and wind power, new systems should be developed that enable renewable energy sources to be integrated into the grid systems which is hardly done in today's old technology used by centralized grid systems. In the next session, we will elaborate on those aspects. 


\subsection{Centralized to Decentralized/Localized Power Generation Systems}

Centralized, decentralized and localized systems of power generation have their merits and demerits. Showing the merits and demerits, as well as the reasons for shifting from centralized to the decentralized and localized systems, is the purpose of this section. In decentralized and localized systems, the electricity is distributed to specific geographic areas. Therefore, if electricity is generated in the same place where consumers live, the distribution and transmission costs will be reduced. Meanwhile, in a centralized system of power generation (CPG), there is a long distance between consumers and generation places (Bhatti, H.J. and Danilovic, M., 2018). The electricity moves through all the way, which makes the distribution costly. Thus, switching from CPG to decentralized power generation (DPG) and localized power generation (LPG) becomes necessary, particularly in distant regions, where generation places are too far from end-users. Electricity should be generated from different sources, such as nuclear power, thermal power, and hydropower. A decentralized system of power generation reduces costs and power losses during the distribution [29]. In case of DPG and LPG, electricity generation and its usage are in the same region, which reduces the number of power transmission lines, annuls electricity losses and saves cost.

The pollution level of distributed energy is low. The electricity quality and safety have great significance because Feed-in-Traffic (FIT) system requires intermittent and renewable energy. Skilled engineers and advanced power plants are needed for having lower contamination level in DPG system. Modern electric technologies can give a solution to pollution problems, since they are fully-automated and use renewable resources, such as sunlight, wind power and geothermal energy. With today's technologies, less power plants are required, which increases potential revenues [30].

A decently developed power grid can face increasing electricity demand. Different generation procedures are used by up-to-date Distributed Generators to have a more efficient, secure and advanced electric system. Although a CPG mechanism has similar features, its construction and usage are expensive, and in some regions, electricity distribution through CPG is complicated. At the same time, DPG is discontinuous and has zero transmission costs. Thus, the integration of a DPG system becomes cheaper and more efficient in comparison to CPG [31].

\subsection{Traditional Grid to Smart Grid}

Due to growing electricity demand, further usage of the existing traditional grid becomes a difficult task. The traditional grid is old, and does not contain appropriate and safe generation and distribution mechanisms [32]. Moreover, the traditional grid uses CPG, which works based on fossil fuels and throws hazardous gases into the atmosphere. Thus, the traditional grid now has become an inefficient, expensive system, which is dangerous for the environment and to health 
[33]. According to Feisst et al. [34], 25\% of global greenhouse gases is pollution caused by traditional grids. Present-day technologies are not feasible with the traditional grid, which cannot integrate solar, wind energy, low-inertia sources of electricity generation and distributed generation system [33].

Meanwhile, current research proves that a smart grid is suitable for use with a renewable energy and distributed system since it contains contemporary technologies for electricity generation and supply. A smart grid can automatically identify system conflicts and fix them, thus providing reliable protection from external dangers and cyber-attacks [35]. Currently, smart grid is a wide research area [36]. Atteya et al. [37] state that renewable energy system integration and serving as a storeroom in a distributed system are a small part of smart grid features. A smart grid provides a reduction of greenhouse gas pollution, a decrease in fossil fuel consumption, as well as makes electricity generation and distribution much cheaper. Furthermore, in a smart grid system, electricity consumers are at the head of the charge since smart grid allows end-users to control electricity usage and get electricity equal to their demand [35].

The changeover of non-renewable to renewable energy sources is reinforced by the depletion of fossil fuels, its high cost, environmental safety and disruption in technology. Even though without proper government regulations, economic tendencies are going towards renewable sources and costs of renewable energy will be reduced more, while costs of fossil fuels are expected to grow. Solar and wind sources require the least cost to generate energy yearly because it is facilitated through natural resources. Furthermore, shifting from a centralized power generation system to a decentralized and localized system is recommended because these systems are highly equipped and can easily be integrated with renewable energy sources. These power generation systems are close to end users which reduces the cost of transmission lines and annual electricity losses. Finally, the traditional grid is an old "stupid" power distribution system. It can only be integrated with centralized power generation systems, runs on fossil fuels and emits greenhouse gasses which are harmful to the environment whereas, a smart grid is an "intelligent" system. It can easily be integrated with renewable energy sources and supports decentralized and localized power generation systems which help to provide clean energy at a low price to the consumers.

\section{Disruptive Technology}

According to Kuhn [38], if new technology completely changes existing technical standards, mechanisms or models, it is called a "disruptive technology". The industry of telecommunication describes the influence of disruptive technologies by emphasizing all obstacles and chances, which the electric utility industry is facing now. The telecommunications industry had high entry barriers in the 1970s because at that time the business was capital-intensive and government regulations were higher [11]. The development of mobile technologies strongly affected income sources of telecom companies. As a result, rules and regulations changed for the whole industry in order to maintain competition between firms. 
Thus, the telecommunication industry of the 1970s was different from today's one. Large US telecom companies, such as Verizon and AT\&T, changed their business models and developed marketing methods in order to keep leading position in services of the wireless telephone. In the same vein, in the 1990s, Internet technology development enabled people to communicate more easily [39]. For example, due to the modem, customers could access the internet by computer or telephone. This development encouraged telecom companies to interconnect the system of household communication and provide more and better telecom services [39].

According to Qiu [40] disruption relates to new knowledge, processes, products or services. Furthermore, disruptions could relate to new rules and regulations. For instance, recent disruption occurred in the US immigration policy where new rules and regulations are imposed on newly applied visa candidates. When social relationships are transformed, it could be disruptive as well [41]. Neither existing market nor disruption of existing technological standards disrupts emerging technologies. It is caused by the transformation of the existing capitalism model, social relations, and business-structures, which are more significant disruptions. According to Gonzalez [42], a Keurig K-Cup single-serve coffee machine is an example of a disruptive technology. In the 1990s, a single-serve plastic coffee pod, which is called a K-Cup, was invented by John Sylvan. Initially, the K-Cup was for office use. However, Hamblin [43] mentions that the new product started to conquer the market after Keurig Green Mountain purchased it and advertised it for home usage. The company sold 9.8 billion individual coffee pods in 2014, which would circle the equator 10.5 times, if placed end-to-end. The coffee pod and single serve coffee machine disrupted the coffee market. Therefore, disruptive technologies influence other industries and social norms. Eventually, disruptive technologies make severe changes in society, physical environment, institutional rules and in organizational structures.

\subsection{The Disruptive Innovation Model}

The track of product performance is presented in the diagram, which consists of red and blue lines. The blue lines represent the desire of customers to purchase the products or services, while the red lines display the improvement of products or services as shown in Figure 6.

When incumbent firms are entering the market with exclusive products for rich customers (upper red line), the firms' profitability is increasing. At the same time by reaching to the high end of the market, firms are skipping the opportunity to meet lower level or mainstream customers' demand, which is a lucky chance for new players to catch lower segments of the market. By starting from the lower end, new players ameliorate their products over time and make the path towards mainstream or high-end market. A lower red line represents the disruptive trajectory. Thus, incumbent firms receive competition from new players with disruptive technologies [44]. 


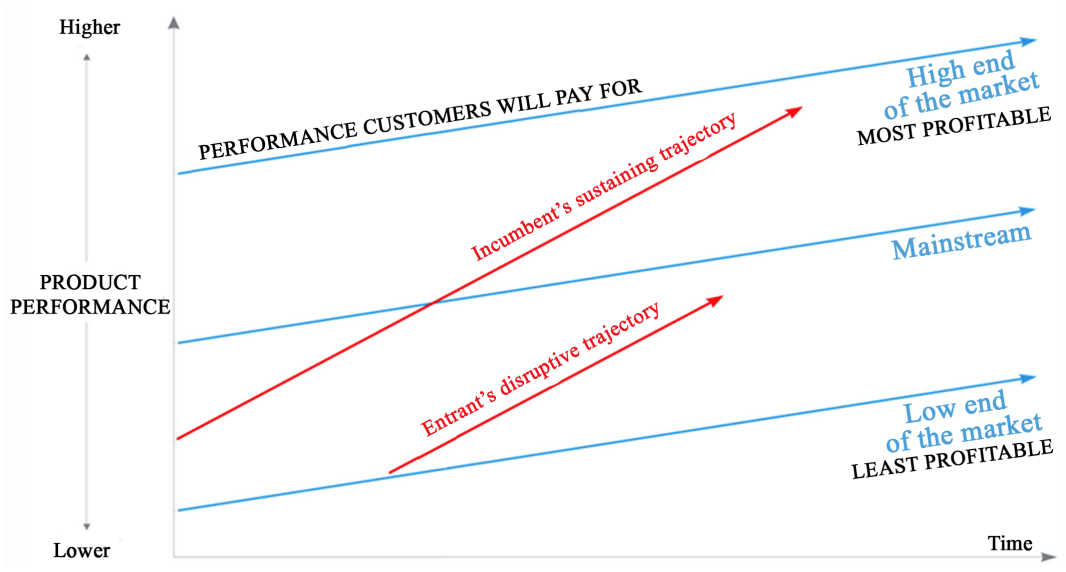

Figure 6. Disruptive innovation model [44].

\subsubsection{Implication of Disruptive Innovation Model in Energy Sector} An example of a disruptive technology is the distributed generation (DG) of renewable energy. The following section presents DG in the German electricity market based on three standards of disruptive innovation by Christensen [45].

\subsubsection{Low-End/New Market \& Return-on-Investment}

Research showed that until 2016 Germany was facing a low level of investment in the renewable energy sector. During 1990-2010 German electricity firms, such as Eon, ENBW, Vattenfall, RWE, invested in fossil fuels and nuclear energy technologies while only a slight part of investments went to renewable energy generation. The reason was the high profitability which was provided by electricity from fossil fuels and nuclear power generation. Electricity companies showed that there is interest in renewable energy when feed-in tariff (FIT) plans debuted at the beginning of $21^{\text {st }}$ century. It was estimated that due to FIT plans, Return on Investment (ROI) from renewable energy generation would be twenty years. Nonetheless, after FIT debut, utilities are still temporizing the investments in the renewable energy sector (RES) because of its small size. In the early 2000s, overall capital of RES was relatively smaller than average investments in the electricity sector. During that period, technologies of renewable energy did not have any significant advantage over traditional power plants. Furthermore, power plants provided additional services as well, including frequency management and control over voltage.

Thus, during its market entrance stage, renewable energy focused on the low-end market and had low profitability. Meanwhile, decentralized generation technologies have been developing, and currently, they can provide renewable energy generation from house roofs and verandas, can provide a higher level of revenues with auxiliary services, and have higher security unlike centralized generation [45].

\subsubsection{From Low-End and New Market to Mass-Market Based on a New Feature}

Utilities are not the only players in the electricity market. Unlike electricity 
firms, other actors, such as cooperatives, households, and farmers, have been showing more interest in renewable energy primarily because other actors are satisfied with the ROI level. Moreover, renewable energy generation is more beneficial from an environmental perspective since it has zero level of $\mathrm{CO}_{2}$ outflow. Consequently, decentralized generation expanded in Germany swiftly. The growth rate of renewable energy generation in Germany during 1990-2015 is presented in Figure 7 [45].

It took 15 years for renewable energy technologies to have full market entrance. The enhancements in quality and security are required to achieve the market demands. Figure 7 shows that farmers and households are the primary investors of Germany's renewable energy sector. In 2012, utilities provided only $12 \%$ supply of 73 gigawatts (GW) of renewable energy, and $46 \%$ of the electricity was provided by households and farmers [45]. Government rules and regulations have a massive impact on the electricity market. Although utilities can invest in renewable energy, they do not hurry to do it. The traditional power plants' market share and revenues will be challenged if utilities decide to invest in renewable energy technologies. However, currently, electric companies are more in favor of maintaining their market share and income level by using their power plants. It is visible in Figure 7 that growing shares of renewable energy reduced revenues from gas-fired power plants, and overall electricity price shrunk due to renewable energy [45].

According to Christensen, some strategies are applicable for integrating disruptive innovations. One method is the business unit splitting, which applies to establishing a start-up focusing on disruptive technologies, for instance, renewable energy generation. The core of business unit splitting is that the whole company should be involved in the disruptive innovation, and not only its separate units. If a new company focuses on innovation, its business model, strategy, vision as well as a culture will cover all its business units. In 2016 the German companies "RWE" and "Eon" followed a business unit splitting scheme and created a new business unit focusing only on renewable energy generation.

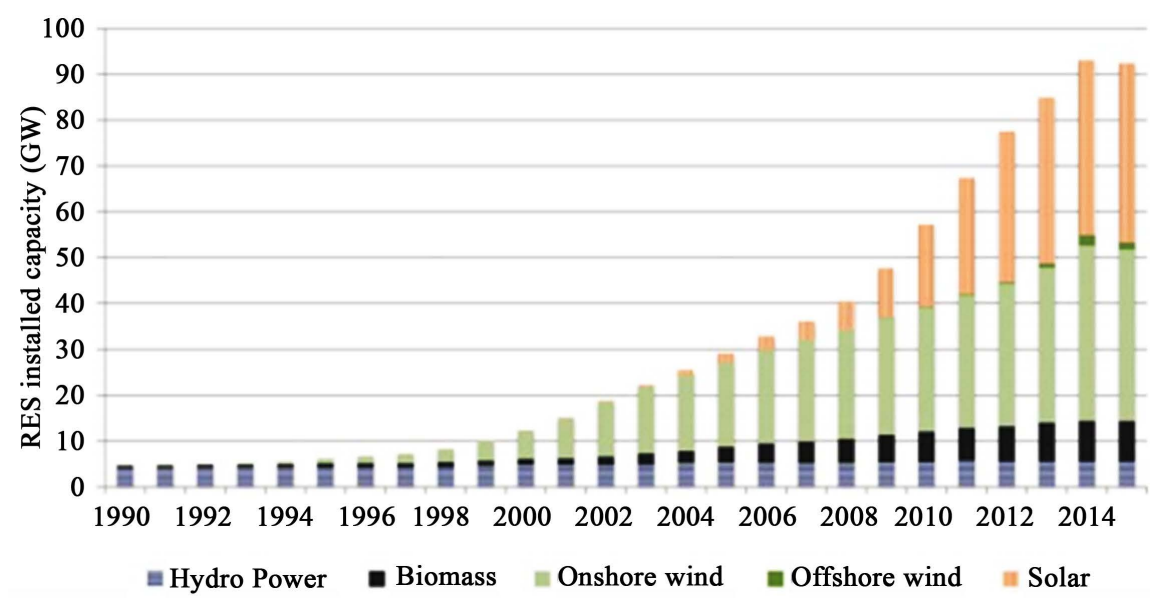

Figure 7. Growth of renewable energy sources in Germany from 1990 to 2015 [46]. 


\subsection{Disruptive Forces: Lessons Demonstrated by Other Industries}

The concept of "disruptive forces" is used to explore the limitations of current business models and innovative products, which transform the market. To demonstrate the importance of reestablishing the business models of the firms along with the advancement of technology, four vivid illustrations such as; Kodak, Tesla, iPhone, and Nokia have been quoted. These four firms are associated with three different industries; photography, automobiles, and mobile respectively. These firms prove that only depending on the advancement of technology is not sufficient for survival in the market or gaining more profit but along with it, establishing a new business model is key for commercializing your products or services in the market against your competitors.

Kodak: Eastman Kodak many years ago was a leading company in the photo film industry. The year 1888 was revolutionary for camera and film industry because "Eastman" company, which would become known as "Kodak" in the future, introduced its first camera. In 1900, Brownie, the first pocket camera was introduced, which had transformational success. It was cheap and easy-to-use. These products allowed Kodak to get huge profits and invest it in R\&D. In 1935 Kodak created a color film camera, which could make high-quality color videos and photos. Later Kodak was involved in the development of X-ray cameras, color printers and space pictures in 1962. During the $20^{\text {th }}$ century, Kodak was an incredibly successful company. However, the company started declining when digital technologies entered into the photo business. The reason behind the failure of Kodak was the misused opportunity opened by disruptive technologies [47].

The main disruption in the camera industry is concerned when cameras were merged with mobile phones. When mobile phones started to include features such as taking photos and sharing them, people began to post pictures on social media. The quality of electronic pictures eventually defeated the quality of printed pictures. Kodak invented the first digital camera. Furthermore, when the internet started to expand, and users got the opportunity to share images, news, and other information, Kodak made a strategic move in 2001 and purchased photo sharing website, which was called "Ofoto". At that time, Facebook and other social networks did not exist. Thus, "Ofoto" was an excellent chance for Kodak to revise its core business and move into the digital sphere. Nevertheless, here Kodak made its most significant mistake and refused to change the business model even though they focused on digital media [48]. Instead, Kodak used "Ofoto" as another way to print pictures. The company used the webpage to get more customers for photo printing. For several decades the company was a market leader in the film industry, but when digital technologies came into the arena, Kodak tried to use them as a way for growing its sales instead of changing its business model. The company asked the wrong marketing question, which was "How we can sell more products?" rather than the question which should have been asked which was "In what business we are in now?" If Kodak had rea- 
lized that the old camera and printed picture technology would not be their core business in the future, then the company would have survived.

On the other hand, Kodak's main Japanese competitors Fuji Films, Canon and Sony were actively trying to upgrade their business model by making new products such as optic tapes, videotapes, digital cameras, printers and office automatization equipment [49]. Thus, inventing or innovating a disruptive technology is not enough for success. The most important is a business model innovation which can commercialize the products or services to compete with similar companies. Therefore, Cuthbertson et al. [47] stated that Kodak had been a valuable lesson to companies that they should understand that disruptive technologies require a new business model innovation for their new products or services to be commercialized with new ways which can keep the old, as well as draw new customers.

Tesla: It was just ten years throughout which Tesla Motors has moved from zero to the top innovative company in the world. The company produces electric vehicles and engines. The headquarter of Tesla is located in California, Silicon Valley, which creates a more innovative atmosphere in the company [50]. Tesla is famous for its magnificently-designed electric cars and brand. The company is targeting wealthy customers by offering them luxury cars with high quality, comfort and modern technical features [51]. Due to the target market, Tesla is getting high profit. However, the strategy has a negative side as well because there is a small percentage of wealthy customers. Thus, general sales have limits [52].

Disruptive technology drives towards new development [53]. The concept of the new electric affordable car is one of the results of the disruptive innovation [50]. Tesla integrates innovative ideas and makes them real by developing new methods of the electric car and engine production [54]. Furthermore, Tesla is investing more in research and development to emerge with better electric vehicles. Many technologies, such as 18650 ternary lithium-ion batteries, as well as dual engine drive with all-wheel, are used only by Tesla Motors. Tesla Model "S" won US high speed Road Safety Authority and European Euro NCAP prizes for safe cars.

The unique business model is the core of Tesla's success, which includes great customer experience, easy understandable instructional guide and security preferences [50]. Further success factors are mentioned below:

- Strong positioning in the market: Tesla has a clear vision regarding its customer. Based on customer segment, Tesla develops its business model. Tesla's first preference is to produce expensive, beautiful and fast sports cars for rich and famous people who care about the clean environment. Second, preference is to manufacture cars which are less expensive but comparatively equally in cost with Mercedes-Benz and BMW electric cars. The last choice is to produce low priced electric cars for families and vehicles which could be used as public transport [55]. 
- More focus on capital investments: Huge investments are required for innovating the business model. Tesla uses retailers to promote its additional services, such as long-term leasing, outsourcing, and capital funds. Tesla purchased substantial capital through US Department of Energy's Advanced Technology Vehicles Manufacturing projects [50].

- Assets Management: Tesla uses outsourcing companies for car production, and the company itself gives more concentration to value-adding, mainly for marketing and distribution. The company Matsushita Electric is producing electric batteries for Tesla and Tesla is focusing on the development of battery technology [50].

A new industry of electric vehicles will be based on business model innovation. The sector of electric vehicles creates a new business model through relationships between its sectors, as well as with government. This relationship includes government support for new infrastructure. Companies should have the main role in creating advanced electric vehicles and distributing them using a new business model. Thus, the new business model is required for disruptive electric vehicle technology which can help them to commercialize electric cars as well as to gain the support of the respective governments for further research. However, when Tesla started to develop a low-priced Model 3, the demand for large-scale manufacturing was a necessity that Tesla did not have and could not easily cope with. Still, until now the transformation from a specialized, small-scale manufacturer to large-scale mass production of electric cars is not seen as a success. The business model of Tesla is still not proven to be successful for the new Model 3. If they fail, the entire survival of Tesla might be challenged.

iPhone: iPhone is an excellent example of business model innovation for disruptive technology. Although smartphones were existing until iPhone's debut, it disrupted the market and left the giant firms, such as Nokia and Blackberry almost out of business. iPhone captured the same target market as incumbents, but the smartphone succeeded because of its quality and unique features. Until 2007, people accessed the internet mainly via laptops and PCs (personal computers). With iPhone's introduction, the internet became accessible from smartphones as well. Later Apple introduced the "App Store" on iPhone which created a new business model where app developers can meet with customers through the App Store. Thus, easier internet access and anew business model are the underlying factors of Appel's success [44].

Nokia: For almost a decade Nokia was setting the game rules in the mobile industry. However, in 2007 Nokia was challenged by Apple which weakened Nokia's positions. After the entrance of the iPhone in the market, Nokia tried to maintain its position but soon got attacked by Google and Samsung. Nokia started to fall rapidly. The company attempted to return through partnership, and was later acquisition by Microsoft, but not any significant developments occurred. Similar to numerous companies, Nokia was not sufficiently flexible and failed to innovate its business model [56]. Nokia could not understand the new market trends and deliver new value to their customers like Apple, Google 
or Samsung did. For Nokia, mobile phones were serving mainly as a mean for communication and the company failed to understand that a mobile phone could have more functions. Nokia's vision was not clear, and their technology Symbian from creation did not have any essential system upgrades [56]. Nokia disregarded the threats from Apple in 2007, and the company continued to use the same business model. When Nokia realized what happened, it was too late already. The company paid more attention to hardware development rather than on software and operating system. Meanwhile, the competitors quickly came up with regular updates and new software. Disruptive technologies were underrated by Nokia [57].

The cases of Kodak, Tesla, iPhone and Nokia serves as illustrations of companies that need to find balance between new technologies and new business models. Otherwise, their commercial success might be questioned despite technology success.

\subsection{Smart Grid as a Disruptive Technology}

The smart grid is one of the future's most powerful technologies, and it has the full potential to be disruptive to energy providing firms, as it can change the entire process and structure of the energy market [21]. Richter [58] stated that the term "disruptive technology" in the energy industry is mostly associated with solar PV and electricity storage because these technologies have had a massive impact on centralized power generation. Disruptive technologies, such as solar PV and electricity storage, support the concept of decentralized and localized power generation systems which give open access to households to generate power for their home usage. As per Cardenas et al. [59], the association of the smart grid with information and communication technologies is very influential, because the use of ICT in the smartgrid plays an essential role in transmitting and distributing energy. According to Zhou et al. [60], smart grid is an emerging technology which is transforming the whole energy industry. It can easily be integrated with different energy objects; such as; electric vehicles, natural gas, energy saving devices, and renewable energy sources. Yigit et al. [61] stated that information and communication technologies have made it possible for homes, buildings, and communities to make them smart and integrate and connect with each other through the help of advanced metering, sensing, and digitalized communication systems. Furthermore, Zhou et al. [62] pointed out that developing market strategies for the targeted market, and understanding the demand of customers and essential data technology can support and help the energy service providers. Niesten et al. [63] and Welsch et al. [64] stated that several scholars have claimed that there is no technical and functional existence of a smart grid yet but they claim that this disruptive technology is going to make its emergence soon.

According to Colak et al. [65], a disruptive technology has transformed the electrical industry and made it possible to integrate communication and information technologies into traditional electric grids and permit two-way flow of 
electricity and information between consumers and generators. Siano [66] explains that modern technology such as smart meters, communication networks, and data management systems made it possible for consumers and service providers to transmit and receive information regarding usage and demand for energy. Thus, these technologies are the requirements, if any energy providing firms are planning to offer smart grid services to their consumers [67].

Electric utilities used to have two ways of increasing revenue. The first way is to expand the electricity sales or in other words, to increase consumption volumes. The second method is to charge higher prices for per unit of sales. For decades, investors got revenues due to these methods. However, for the future, electric utilities need to change their business models for getting higher revenues and for satisfying the requirements of investors [68]. Prices for electricity are a function of consumption volumes. Electricity companies need to charge higher rates for remaining volumes if sales of electricity decrease, which could be caused by the more efficient use of power, programs of demand management, distributed generation, and other changes. More charges will help to cover the capital cost or service cost. When the prices of electricity are growing, users are starting to reduce electricity usage through programs of demand management and innovative technologies. This situation is described as a "death spiral" by the media. Grace [2] brought the example of the Western Australian South West Interconnected System when the high prices of solar PV resulted in the reduction of consumption because most customers could not afford that high price.

However, nowadays industry analysts and researchers have less concerns about consumers, who are going off-grid and causing a "death spiral" for electric companies. There are high expectations that the majority of consumers will keep their network connection despite electricity storage. The reason is that consumers understand that batteries have technical limitations and the distribution network has its benefits, such as the trade of surplus energy between local regions, and the generation of solar energy should be high in the peak of demand [69]. Instead of making investment limitations for electric utilities, solar PV utilization should be considered. The enormous amount of energy could be accumulated due to the usage of solar PV systems, which will require significant investments in smart grids and grid-scale batteries. Although electric companies will have lower incomes from traditional generation methods, extra earnings from smart grids and solar technologies will compensate their loses [69].

Therefore, Tayal [68] stated that due to easily accessible and cheap capital, as well as customer monopolies, electric firms have avoided disruptive challenges for a long time. Electric utilities should consider the effects which disruptive threats have had in other industries such as policy changing, technological innovation, and the preferences of customers as well. These threats should be considered while making plans for business growth and business strategies and companies should be willing to change their business models along with accepting new technologies. Moreover, Faucheux et al. [70] stated, that it is necessary for the energy providing firms to develop new or redesign their business model. 
Thus, they can create and capture value on a larger scale by providing smart grid services to their customers whereas Johnson et al. [71] stated that for the complete change of the energy industry, it is crucial to develop a new business model concurrently with the rapid shift in technology. There are lots of business models that exist that focuses on value creation and capture, but Teece [14] focuses on the value proposition for the customers. Magretta [72] raises a couple of questions, what should we provide to the customer? How do we generate money through energy providing services? Finally, Zott et al. [73] say that the business models must discover the answer to both value creation and value capture.

Disruptive technologies can disrupt the physical environment, society, business strategies, institutional rules and organizational structures. The reason behind the failure of Kodak was the misused opportunity opened by disruptive technologies. Kodak tried to use digital technology as a way of growing its sales instead of moving from old to new technology and without changing its fundamental business model. Kodak failed because they did not shift the operational model and did not develop a new business model. Whereas, on the other hand, Tesla used a disruptive technology as a tool to introduce a new car solution, improving the quality of their cars, but was more focused on the business model to commercialize their electric vehicle successfully. The incredible news is, Tesla itself does not manufacture! They outsource most of their electric vehicles while Tesla itself concentrates more on value adding, commercialization and distribution. Nokia disagreed with the new market trends and challenges and continued to use the old business model, and by the time they realized that it was wrong, it was too late already. Whereas, the success of Apple is hidden in the understanding of the new market demand, and acting accordingly which enabled them to defeat Nokia and replace it as the new market leader. Finally, in the electricity industry, the smart grid is a future powerful technology, and it has full potential to disrupt the energy providing firms, as it can change the entire process and structure of the energy market. Energy providing firms should consider the effects which disruptive threats had in other industries such as policy changing, technological innovation, and the preferences of customers as well. These threats should be considered while making plans for business growth and business strategies. Therefore, they can create and capture value on a larger scale by providing smart grid services to their customers. It is crucial for the utility firms to develop a new business model concurrently with any rapid shift in technology.

\section{Business Model and Smart Grid}

A smart grid is an electric energy distribution technology which enables utilities and end-users to get full usage of data and aims to utilize electricity more efficiently and flexibly to adapt to variation in production and consumption [7]. A smart grid is equipped with a rich apparatus, such as a network of communication, smart meters for users, and automated data gathering devices [74]. These integrated technologies of a smart grid allow electric utilities to provide quality services to end-users [66]. However, only technologies are not sufficient to make 
full use of a smart grid. Electric companies are required to transform their business models because a smart grid changes the traditional value network for electricity [7].

Smart grid technology and a new business model enabling commercialization of a smart grid system in a localized and decentralized system are the two principal components to start the process of renewable energy economy evolution, which includes the switching from fossil fuels to an economy based on renewable energy sources, a smart grid and electric cars [71].

A dozen theories describe the business model in various ways. However, most of them connect the business model with creation and capture of value. For example, a business model is a tool which shows how a company will create and deliver value to its customers and how a company can get profits [14]. Chesbrough et al. [75] stated that business models describe the running structure of the businesses. Baden-Fuller et al. [76] explained that through business models, companies and markets could be compared and analyzed to determine effective ways of doing business. Johnson [77] pointed out that for managers, the business model is a tool to examine their businesses and develop them further. However, Magretta [72] suggests two questions that companies should ask themselves when making their business models: "What value are we going to deliver?" and "How can we get profit from delivering the value?" Business models should clearly show the value creation and delivery [73].

This paper focuses on business models from value creation and value capture viewpoints. Nine building blocks of business models are described by Osterwalder et al. [78] and Table 1 contains information about how companies are creating and capturing the value through these building blocks.

Table 1. Business Model and its nine building blocks [78].

\begin{tabular}{|c|c|}
\hline Value proposition & $\begin{array}{l}\text { What value can the new smart grid system create for energy } \\
\text { producers and consumers? The focus is on a combination of } \\
\text { products and services, through which companies } \\
\text { create and deliver value to clients and get profits. }\end{array}$ \\
\hline Customer segment & $\begin{array}{l}\text { Targeted customer whom the value would be } \\
\text { an offer by the company. }\end{array}$ \\
\hline Distribution channel & $\begin{array}{l}\text { Ways of the approach used by the company } \\
\text { to reach to the customer. }\end{array}$ \\
\hline Customer relationship & $\begin{array}{l}\text { The companyestablishes and maintains a relationship } \\
\text { with its specific customer. }\end{array}$ \\
\hline Key activates & $\begin{array}{l}\text { Combination of different activities in offering } \\
\text { and delivering value. }\end{array}$ \\
\hline Key resources & Assets and technologies required to offer and deliver value. \\
\hline Key partners & $\begin{array}{l}\text { Suppliers and partners who are involved as support in } \\
\text { offering and delivering value. }\end{array}$ \\
\hline Cost structure & The cost involved to execute the business model. \\
\hline Revenue model & Shows how production costs and profits related to each other. \\
\hline
\end{tabular}




\subsection{Modern Trends in Electricity Market}

Currently, consumers want to control electricity usage more than before [10]. Consumers are paying more money for electricity due to modern gadgets and higher prices for electricity. According to Mardookhy et al. [79], recent research on electricity usage and end-users attitude shows that most consumers are dissatisfied with the current electricity system. For example, $82 \%$ of survey respondents consider that electricity prices are too high and new mechanisms should be integrated to measure electricity usage more effectively. More control over electricity consumption could be gained through smart grids, which have visual displays for showing live data about usage of electricity [80]. However, the smart grids' features show that usage data could decrease the profits of electric companies. Thus, if companies want to integrate a smart grid system, they need to change their business model and the value they are offering [81]. Mainly, the companies need to offer electricity efficiency services in more flexible ways instead of only providing electricity [82]. In other words, electric companies will offer energy services and not electricity itself. However, the energy industry needs a higher level of maturity for integrating the new business model. With the help of smart grid systems, they can adjust leverage and delivery according to a variation in demand with different prices, which is difficult in today's "dumb" system.

The next trend in the electricity industry is customers' changing attitude towards electric vehicle usage. In order to charge the battery of electric vehicles, more electricity will be used, which will create additional pressure on grids. The pressure will be increased when battery charging is happening during the power usage pinnacle [83]. Thus, electric companies could deliver new value to consumers through constructing sufficient stations for recharging, which can take more pressure [84]. However, electric vehicle usage is actively concerned with government policies and regulations, because electric companies will start to deliver new value when the government gives support to electric vehicle market through new policies [85].

Another trend in customer behaviors is their expectations of high quality electric power and better delivery without power interruptions. Smart grids are equipped with several units connected to each other. This feature could provide better and uninterrupted electricity [86]. The smart grids' advanced mechanism can show electrical system problems immediately, which allows companies to fix technical issues by switching between diverse power delivery sources [10]. Because of the vertical integration level of electric companies, they can focus on supply quality as a value to deliver to customers. When new government policies were introduced in the European electricity market, generation, transmission, and supply became separate stages [87]. Outside of Europe, mainly electric companies with vertical integration exist, which assumes that a single company is controlling all stages of electricity generation and delivery. Many markets have companies which are specialized only in electricity delivery. These companies 
are called electricity retailers. Smart grid systems will not be valuable for electricity retailers since the generation of electric power is not a focus of these companies.

A new area of usage of the smart grid system is the electric road system which is being developed that enables small cars as well as large vehicles, buses, and trucks to charge while driving on solar roads, with wires in the ground and in the air. Regardless of the chosen technology, there will be localized energy production that needs to be integrated with local dynamic consumption and the rest not used can be integrated into the grid system. To enable these innovations, smart grid systems are needed.

A smart grid has the capability to affect the relationships between consumers. Traditionally, electricity usage information was managed only by large companies in a centralized distribution grid system. As a smart grid provides electricity usage data to consumers, they can have more significant control over electricity. Furthermore, consumers can choose their electricity service providers, which give the opportunity to create trade relationships with electric companies. Meanwhile, electrical firms can benefit from consumers' increasing authority, because the firms can allow consumers to control the electricity system ("demand response") [80]. This permission includes the opportunityfor consumers to shift electricity load based on pinnacle electricity usage time and the time with the lowest level of electricity usage. Faruqui et al. [88] state that investments in a smart grid will be productive only in cases of mutual benefit for both electric firms and consumers, when through the smart grid, firms are giving and receiving electricity usage data and allowing consumers to control loads in response. Thus, demand response and transparent data are significant components of the new value created by electric firms. Nonetheless, many consumers are not willing to control loads, and electric companies should try to solve this issue by offering new services to customers in order to enhance customers' participation [89]. For instance, companies could gain demand response by offering advice on how to use electricity efficiently [90], real-time feedback [91], equipment for measuring and controlling electricity [92] as well as pricing signals and micro-generators [88]. Research shows that these offerings can give positive results [80] and consumers attitude depends on their education, income level, thinking and specific climate in different regions. Thus, new value creation is based on demand response, which relates to the level of consumers' involvement [93].

The new Millennium has created an arena for new technologies, which has created new customer needs. Customers have changed their attitude and the way they perceive value. The smart grid system is an opportunity for electric companies to fit the new customer requirements [21]. Presently, customers have more awareness about environmental issues, and they follow new government regulations, for instance, feed-in tariffs, aimed to decrease the usage of fossil-fuels [94]. Consequently, customers are more worried about environmental cleanliness [95]. 
As per Smil [96], societies have been taking into consideration issues relating to changes in climate, sustainable energy demand, as well as the development of the sustainable economy, which is built on renewable energy sources. Nowadays, the concept of global warming is a widespread topic of discussion. Lehtovaara et al. [97] stated that during the $20^{\text {th }}$ century, over $1^{\circ} \mathrm{C}$ global temperature rise was registered. Furthermore, more temperature rise is expected throughout the $21^{\text {st }}$ century because the concentration of carbon dioxide $\left(\mathrm{CO}_{2}\right)$ could increase up to 450 parts per million in the atmosphere [98]. According to forecasts, in 2050 humanity will consume $50 \%$ more energy than today, mainly caused by increasing gross domestic production (GDP) and population growth [99]. In 2050, $\mathrm{CO}_{2}$ emissions will increase up to $130 \%$ in the case of maintaining current levels of energy consumption and global warming [97]. As a result of increased emissions, global temperature will rise more than $6^{\circ} \mathrm{C}$, which will severely damage the environment and society.

Fortunately, the problem of global warming has an optimal solution, which can decrease current change rates. The answer is concerned with the usage of renewable energy sources, including wind, hydro and solar energy, biomass and geothermal [98]. By using renewable energy through integrating smart grid system, electric vehicles and a new system of energy storage, climate issues can be solved [100].

Markets of wind energy are boosted by growing demand for energy and climate change issues. The decentralized and localized power generation systems can fulfill the growing demand for electricity which can be integrated with wind and solar energy [101] and biofueled combined heat and power production [102]. A biomass energy system should be integrated into those areas which are more abundant in natural resources [102].

Smart grid integration is a new and unexplored way to adapt and manage renewable energy sources which provide clean energy [10]. Although, integration of renewable energy sources will distribute the profitability of electric companies with ICT companies, investing in renewable energy will be a wise decision for them because the public requires a "green environment" [95]. One drawback is insufficient governmental support in the renewable energy sphere [103]. Despite that, governments of many countries have introduced new regulations. Still, there are lacks in governmental support. Therefore, new government policies for the energy industry will be the next step towards smart grid integration.

\subsection{Response of Electricity Market Trends}

As mentioned above, nowadays consumers are demanding sustainable power as well as control over their electricity usage. In order to maintain market position and gain profit, electricity firms need to follow these rising trends by providing new services. Companies can provide full services for installing and optimizing the generation machines, and they can charge optimal prices or offer free services. 
Consumers may get help from electric companies when purchasing devices or kitchen instruments, which are energy-efficient. The US electricity company Duke Energy is buying consumers' old electric equipment and appliances and offers free energy-efficient bulbs. Electric firms can make partnerships with appliance producers and offer installment services or discounts to consumers. The companies can offer an advanced system of home energy [80] or remotely manage appliances' operations [104]. Prosumers, who organize home-based renewable energy generation, could get assistance from electric companies to manage their operations. For example, companies could give advice relating to the efficient use of energy and support the generation apparatus to serve for a long time [95].

Energy consumers' information provided to the retailers by a smart grid with the help of "big data" technology is the first way to increase revenue level. Electric companies can offer electricity usage feedback for the specific time period. Consumers would allow electric firms to gain data about electricity usage and users' demography. Then firms can use gained information for new value creation or to optimize the grid. Furthermore, electric companies can develop their business models to take advantage of detailed usage information, such as usage type (lighting, cooling, heating). The new business model could include electricity charges based on usage type rather than electricity kilowatt per hour [105]. In addition, various charging mechanisms could be implemented, such as different electricity costs based on what time of the day consumers are using electricity [88].

Consumer data could be used in other ways as well. Firms can sell the data to providers of electric devices, software or other companies in order to help other companies to create products matching with consumer needs [10]. For instance, firms offering energy services could purchase consumer data and use it for making better tips and notifications about effective energy usage. Companies outside the electricity sector might be interested in the data in order to enhance their understanding of the behavior of customers. Thus, electric firms can get profit by selling the data [106]. Despite that, it is not clear what the interest level would be of other companies. Social networks, and online retailers most probably will show interest, and they can be big players in the market [107].

\subsection{Challenges to Offer New Energy Services}

Still, the question of whether to provide the grid services themselves or to give the responsibility to other players is bothering electric companies [92]. Even if electricity companies assign third-party firms to offer grid services, they can still get profits. Thus, smart grid builds a new market, which requires a new business model [108]. The new market contains electric companies, ICT firms and electricity consumers [109]. Inserting new participants in the electricity delivery chain creates new value [108]. This approach is beneficial for electricity firms as well since they can access resources of ICT firms. Electric companies have already established a network of partner suppliers and consumers [106]. It is 
possible for electric firms to generate extra revenue from consumers and service firms by giving them rights to access the data. However, the most significant issue is the integration of more consumers and service providers, because the new delivery chain will be profitable only if there are huge customers and service providing firms [109].

Changes in cost structure are unavoidable during smart grid integration. As new participants enter the market, the infrastructure will evolve, and huge capital investments by electric firms will be necessary. Nonetheless, the investments will save companies from additional expenditures in the future. The main destinations of investments will be facilities of communication, smart meters, controllers, grid equipment, software, and removal of the existing grid [92]. Due to fluctuations in fossil fuel prices, high repairing costs, and high taxes, the existing grid becomes inefficient and expensive [110]. After smart grid installation, electricity firms will face the need to maintain the grid, train personnel to deal with the new technology and spend time on the data transferring process, which requires more capital investments. If electric companies use ICT firms for providing services, grid maintenance will be cheaper. ICT firms could use remote controls over the grid, which saves electric companies from spending money on staff, who would need to physically go and visit smart grid places. Therefore, instead of physically going and fixing problems, electric companies can save money and allow ICT firms to detect and fix system errors from a distance by using cloud computing technology [92]. The same approach applies to other operations, for example, meter reading. A smart grid has to automate data collection technology, which gathers the data and sends it to electricity providers. Thus, there will be no need to keep employees for reading meters. Moreover, automated meter reading eliminates the risk of customer's stealing electricity [88].

Load-shift technology is another source of cost-cutting. If consumers are able to use load-shift technology, it can give $20 \%$ - 50\% investment compensation after installing smart meters. Aminor investment will be needed to build a transmission system since in a smart grid, distributed energy is generated close to the usage place [111].

Thus, the integration of a smart grid system will change the way electric firms create and deliver value. Still, there are uncertainties concerning the financial benefits smart grids can provide, which cause unwillingness to adopt the new system [112]. Features which a smart grid provides, such as power control by end-users, and effective usage of distributed resources of renewable energy, will reduce profits of electric firms [113]. However, at the same time, the smart grid will bring new opportunities and needs, which the firms can use to deliver new value to the consumers and gain more revenue by changing their business models.

\subsection{Commercialization of Smart Grid's Services through Business Model}

This research explores the three services that can be provided through smart 
grid, such as; the services provided by the integration of renewable energy sources with smart grid, services for electric vehicle and demand response services.

\subsubsection{Services to Integrate Renewable Energy}

The process of building an electricity network through renewable energy sources represents the first smart grid service category, which includes two subtypes of services. The link between the electricity network and the sources of renewable energy presents the first sort of service, while the second sort of service relates to retailers or operators, which includes delivering a proper power level and a deeper integration of sustainable energy.

According to Barley [114] companies which are providing solar panels and wind turbine transportation and installation services are more valuable than companies which are producing the solar panels and wind turbines. For instance, a British company Solar Century focuses on solar panel installation services and has integrated a new business model for better service. Customers can lease photovoltaic systems from Solar Century, and the company will install the system. The company's solar panels are purchased by Triodos Bank, which is a partner of Solar Century, and the bank gets profits by offering the panels with feed-in-tariff plans. Another business model is described by Richter [115] which includes the following mechanism: electricity companies who are building an energy network for consumers who generate renewable energy. For example, New Jersy utility launches a solar loan program for local companies, municipalities or households which are willing to switch to the renewable energy system. The solar loan program assumes to cover from $40 \%$ to $60 \%$ of costs for building and installing solar panels, and after that customers get renewable energy certificates, which they can use later for paying off their utility loans. The utility gets to profit from the loans [115]. The business model with information about profits, consumers, assets and main activities are summarized in Table 2 [63].

The second service subtype relates to the delivery of safe and sufficient energy, as well as less side effects occurring from irregular sources of energy, such as solar and wind energy. Since these energy types have an irregular generation, it creates peaks and system errors [116]. Electricity companies and system operators are trying to deliver safe and quality power by decreasing peaks and fixing the errors, which can be achieved through various services. For instance, services include distributed generators, which balance power generation according to fluctuations in price, store the power and send it to the grid. Other services include management of voltage by system operators and demand response services. All mentioned services will be discussed in the following sections. Values provided through smart grid services for different actors by integrating renewable energy sources with smart grid are shown in tabular form in Table 3.

When electricity prices are growing, consumers are allowed to decrease their consumption level, or increase it in the case of price reduction [115]. This method is called dynamic pricing. When prices are increasing, end-users can switch 
Table 2. Customer side renewable energy generation-business model [63].

$\begin{array}{cl}\begin{array}{c}\text { Value } \\ \text { proposition }\end{array} & \begin{array}{l}\text { The utilities sponsor the construction of home-based solar systems. Later consumers generate elect } \\ \text { and get energy certificates, which can be used for refunding the investments. } \\ \text { Customer }\end{array} \\ \text { Segment } & \begin{array}{l}\text { Utilities are doing consumer discrimination for dividing active and passive consumers } \\ \text { through the management of consumers' interface with transparent data. }\end{array} \\ \text { Key resources } & \begin{array}{l}\text { Integration of renewable energy sources equipment's (wind power system and } \\ \text { photovoltaic solar systems) are the essential technologies for electricity generation. }\end{array} \\ \text { Key activates } & \begin{array}{l}\text { Distribution of localized energy production to localized energy consumption on demand. } \\ \text { Surplus goes to the grid system. Utilities for managing resources elaborate new techniques. }\end{array} \\ & \begin{array}{l}\text { Integration is the key component of activities between the production and the consumption side. } \\ \text { Key partners }\end{array} \\ \begin{array}{l}\text { The central partners are the companies which produce renewable energy (wind and solar) } \\ \text { and those building energy systems. Energy distribution actors need to be integrated along } \\ \text { electric roads, and integrated solutions need to be developed with many actors. }\end{array} \\ \begin{array}{l}\text { Revenues for utilities contain loan interests, as well as investments added to property value. } \\ \text { Banks are getting revenue via using feed-in-tariff plan. There is a possible direction that energy } \\ \text { distributors and smart grid system owners will change their value chain position to energy } \\ \text { production in order to control the entire system. Thus, the revenue model will transform } \\ \text { to integrated system providers. However, there is a risk of monopoly. }\end{array}\end{array}$

Table 3. Values through integrating of renewable energy sources with a smart grid for different actors [63].

\begin{tabular}{|c|c|c|c|}
\hline $\begin{array}{l}\text { Services Provided } \\
\text { by Smart Grid }\end{array}$ & Values for Consumers & $\begin{array}{c}\text { Values for } \\
\text { System Operators }\end{array}$ & $\begin{array}{c}\text { Values for Service } \\
\text { Providers/Aggregators }\end{array}$ \\
\hline $\begin{array}{c}\text { Services for } \\
\text { Integrating } \\
\text { Renewable } \\
\text { Energy }\end{array}$ & $\begin{array}{ll}\text { - } & \text { Electricity usage can be reduced } \\
\text { - } & \text { Benefits associated with finance } \\
\text { - } & \text { Good control over Power } \\
& \text { usage and bill } \\
- & \text { Benefits associated } \\
& \text { with the environment } \\
- & \text { Consumers involvement will } \\
& \text { increase in the electricity system } \\
- & \text { Reduction of } \mathrm{CO}_{2}\end{array}$ & $\begin{array}{ll}- & \text { Network and supply } \\
& \text { reliability will be improved } \\
- & \text { Network stability and } \\
& \text { security will be improved } \\
- & \text { Operations associated } \\
& \text { with grid will be improved } \\
- & \text { Peak demand can } \\
& \text { be reduced }\end{array}$ & 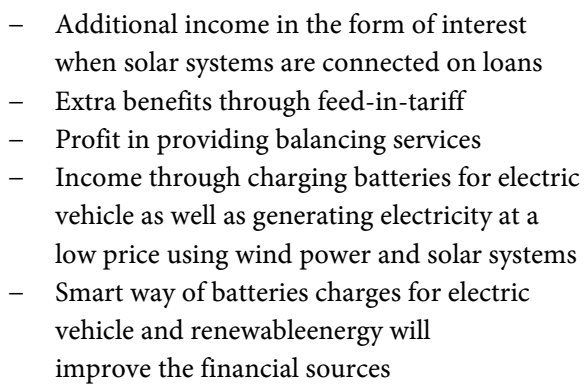 \\
\hline
\end{tabular}

to their own generated sustainable energy. Demand response section contains the description of all sorts of dynamic pricing, such as real-time pricing, time-of-use pricing, and critical-peak pricing. As a result of dynamic pricing, peak loads decline, and the grid operates efficiently during the peak times [115]. Gordijn and Akkermans [116] discuss a service concerning with technologies of distributor generators which are used to stabilize the system. The technologies include combined-heated power which generates and supplies the heat. The providers of this service at profits provide equipment to consumers.

Distributor generators (DG) are possible to add to the distribution system without reinforcements of the network. When overall DG electricity price is growing, management service providers make profits [116]. Electric vehicle batteries can serve as electricity storage, and later send the power to the grid [117]. According to Richardson [118], almost 30\% to 75\% growth of energy capacity is possible if the electric vehicle will store the power and send it to the grid which is 
a vehicle to grid service. Due to this power storage capacity, the electricity network becomes more secure [119], adaptable and efficient [84], and power quality improves [66]. Service providers can make a profit by charging the batteries of EVs during the period of lower electricity prices and growing amount of wind energy [118]. According to Goebel [120], the EV charging process can be more profitable in the case of an increasing number of renewable energy generators, which positively affects the power supply in the short-term. Palizban et al. [121] stated that virtual power plants could store the power and serve as distributed generators. Ultimately, supply and demand can be stabilized through demand response services, and more renewable energy can be generated [122]. Due to this service, the electricity system becomes more secure, and the quality of electricity is improved [66]. Thus, services provided through demand response and V2G and G2V, are more beneficial for smart grid systems because they allow increasing the amount of renewable energy, while improving system security, and power quality.

\subsubsection{Electric Vehicle Services}

As per the guidance of literature, two types of services have been explored in this section. These services are named vehicle to grid (V2G) and grid to vehicle (G2V) services. The batteries of EVs can store electric power, which later energy actors can sell to operators of the system. This process relates to V2G services. Meanwhile, G2V services include the process when energy actors purchase electricity for EV battery recharging. Both services are provided by the EV aggregator, which is the new player in the electricity market. V2G and G2V services can be seen as a platform, which is built by EV aggregators [92]. Furthermore, Giordano and Fulli [92] describe this platform as a business model which combines more than two interdependent groups of customers and products or services that can be offered to the groups.

Niesten and Alkemade [63] mentioned the players that are involved in the platform of service providing and consuming V2G and G2V. These electric vehicle aggregators are electric vehicle owners, the electricity market, system operators and battery switch stations. The electricity demand and supply overlap via EV aggregator, which provides $\mathrm{G} 2 \mathrm{~V}$ and $\mathrm{V} 2 \mathrm{G}$ services for creating and capturing value. EV aggregator uses two mechanisms: firstly, electric vehicle batteries can be charged during the off-peak hours at a lower price than it can be discharged by selling the electricity at the battery stations during peak hours [123]. Secondly, it uses EV batteries as electricity storage and offers the storing services to system operators [124]. Table 4 shows a quick look at the values that are provided through electric vehicle services in the domain of smart grid system for different actors.

The first mechanism, in which EV aggregators purchase electricity at less cost and sell electricity from EV batteries at a high price, was proposed by Armstrong et al. [123]. Niesten and Alkemade [63] mentioned that from price and profit perspectives $\mathrm{G} 2 \mathrm{~V}$ service is more beneficial than purchasing the electricity from 
Table 4. Values through electric vehicle services for different actors [63].

\begin{tabular}{|c|c|c|c|}
\hline $\begin{array}{l}\text { Services Provided } \\
\text { by Smart Grid }\end{array}$ & Values for Consumers & $\begin{array}{c}\text { Values for } \\
\text { System Operators }\end{array}$ & $\begin{array}{c}\text { Values for Service } \\
\text { Providers/Aggregators }\end{array}$ \\
\hline $\begin{array}{l}\text { Electric } \\
\text { Vehicle } \\
\text { Services }\end{array}$ & $\begin{array}{ll}\text { - } & \text { Prices will be lower for energy } \\
& \text { and battery } \\
\text { - } & \text { Clean environment } \\
- & \text { Additional services } \\
- & \text { Financial benefits } \\
- & \text { Consumer participation will } \\
& \text { increase in the electricity system } \\
- & \text { Reduction of } \mathrm{CO}_{2}\end{array}$ & $\begin{array}{l}\text { - } \quad \text { System cost will be lower } \\
\text { - Access will be easy which can help } \\
\text { to improve the regulation services } \\
\text { - Stability and reliability of the grid } \\
\text { will be increased } \\
\text { - } \\
\text { Peak demand can be controlled } \\
\text { Operations associated with supply } \\
\text { and demand can be improved }\end{array}$ & $\begin{array}{l}\text { - } \text { Income from vehicle to grid services } \\
\text { - Providing energy at lower } \\
\text { cost from the grid to vehicle }\end{array}$ \\
\hline
\end{tabular}

electric companies. Thus, it is essential to have a good knowledge about when EVs are arriving during the day, and owners of EVs can get benefit from charging batteries at specific times throughout the day [123]. The case of an EV aggregator, which provides G2V service for EV battery charging, is proposed by Goebel [120]. Although, in this case per annum profit is low for EV owners but there are several methods for getting higher revenues from the G2V business model. Firstly, the EV fleet needs to have a bigger size. Secondly, the batteries of EVs should be charged in specific time intervals, such as between 9 a.m. and noon and between 1 p.m. and 5 p.m. During these time periods, most of the EV owners are parking their cars near to their workplace. The involvement of renewable energy is significant in this case because it stabilizes the power supply and controls charging methods which are profitable financially [120]. A V2G case is proposed by Loisel et al. [125]. The case includes EV fleets which sell electric power to the market. The authors found out that currently, V2G services are not profitable enough since many EV owners are not willing to get the service. The business model should be ameliorated for stimulating EV users. For instance, numerous approaches could be integrated in order to make V2G services more profitable, such as: offering additional services to electric car owners and remunerating them for using renewable energy [125].

The second mechanism is proposed by Kempton and Tomić [119], who analyzed the case of V2G in order to find how companies can create and capture value through offering EV batteries' electricity to the operator of the system. Managers of distributed electricity generation, network providers of mobile phones, retailers of electricity, as well as EV producers and fleet operators, can all be in the role of EV aggregators. Kempton and Tomić [119] determined that the spinning reserves and regulation are the main sources of profits in V2G model. Furthermore, regulation is more beneficial than spinning reserves. Richardson [118], mentioned that service providers are getting $\$ 100$ - 300 profit yearly from a single EV. It is a matter of question whether service providers can engage EV aggregators or EV owners to the V2G model by this profit level. In order to involve owners of EVs aggregators need to offer packaged services, including discounts for battery charge, as well as purchasing and maintaining the battery with preferential rates [126]. According to a contract, the owners of EVs 
are required to charge their EV batteries from the grid at certain hours of the day. Due to lower transaction costs and economies of scale, the EV aggregators can afford preferential rates [126]. The bigger EV aggregation is, the higher capacity for additional services which can be offered by EV aggregator [126]. Some of the EV fleets are providing free space of battery (G2V). This service is called downward reserves for frequency control which are proposed by Jargstorf et al. [127]. Further Jargstorf and Wickert [127] argued that G2V service revenues are reaching from 5 to 16 euros monthly for a single EV. Nevertheless, installation, communication control costs are excluded from mentioned monthly revenues. EV fleet's accelerated battery degradation contains financial risks and Hill et al. [128] suggested that the profitability of V2G model is dependent on the duration of battery service. If the life cycle of the EV battery is short, V2G has low profitability.

According to Niesten and Alkemade [63], Better Place is an appropriate EV aggregator case, which has been studied by some scholars. Better Place is a large international organization, which develops electric batteries, smart devices for battery charging, offers numerous services and software for EVs and operates in numerous countries, such as Denmark, Japan, Netherlands, and Israel. Better Place uses renewable energy sources, which are purchased from the market and makes partnerships with electric car producers, as well as with operators of the grid. Through partnerships, the company connects battery charging places with the grid and serves as a mediator between car producers and system operators. Consequently, EV owners are getting e-mobility services from Better Place through leasing batteries from the company and using switch stations and places for battery charging. Unfortunately, Better Place went bankrupt in May 2013, even though the company managed sizeable capital investments and had numerous partners. The company failed because firstly, the huge time required for the company to enter the market [116], and secondly, the company could not meet the demand for continuous investments [129]. Better Place, as an aggregator, invested in charging infrastructure at the time when EVs were in their initial stage of market entrance. Better Place used a business model requiring huge capital investments. Meanwhile, there are business models with a lower capital requirement [130], which could be implemented in the inceptive dispersal of EVs. Initially, EV owners are charging the batteries at their home according to their agreement with electricity providers. However, when EV sales grow, charging stations should be built mainly on streets and system operators will take the role of station owners [84].

\subsubsection{Demand Response Services}

Demand response (DR) service is another smart grid service in which electricity consumers regulate the load according to the requirement of the system operator or electric utility. When electricity usage reaches to the maximum in rush-hours, operators will ask consumers to reduce the usage level in order to maintain the safety of the system and deliver the proper amount of electricity [84]. The US 
Department of Energy relates demand response with the process of adjusting the electricity usage by the consumers in case of higher prices or serious system errors [67]. Demand response is divided into two types, such as price-based and incentive-based response. When consumers alter the electricity usage according to retail prices, it is called price-based response. It has numerous subtypes, such as real-time pricing (RTP), time-of-use pricing (TOU), and critical-peak pricing (CPP). In case of real-time pricing, consumers in advance are apprised about spot market-based tariffs, and they can adjust the usage appropriately [131]. The day is split into two intervals in TOU approach which includes electricity charges collected through on and off-peak tariffs [120]. If the price of electricity rises rapidly and the grid cannot meet peak demand, then the critical-peak method is used [132].

Incentive-based response method offers electricity regulation which is not connected with retailing prices [67]. In this model, electric utilities pay consumers and in response get permission to manage electricity load distantly [66]. Utilities can regulate electricity for the appliance. Nonetheless, consumers can choose to partly modulate the load and thus, interact with the utilities [133].

Thus, a new player is entering the market due to demand response service, and it is called demand response (DR) aggregator. According to Dave et al. [134], DR aggregator is an entity which controls a load of electricity in order to regulate the grid system and have lower peak demand. Aggregator provides electricity to the market, retailers, or actors who stabilize the power and maintain electricity on a safe level. While some stabilizing actors demand only 0.1 MW power for getting it from various sources (for example demand response), mainly actors need at least $1 \mathrm{MW}$ electricity offer [135]. In any case, quite higher load levels should be produced by demand response service providers, particularly in urban areas. For having a lower load, up-front and on-going capacity payments are becoming widespread [67]. DR aggregators strive to have lower costs and higher profits; these payment methods are appealing to them. If electricity retailers need to purchase services of active demand, consumption and flexibility can be offered to them by the aggregators [92]. Therefore, aggregators are getting profits by providing services of demand response to retailers, stabilizing actors, and the market. Meanwhile, due to regulating their usage level and to being involved in the demand response services, electricity consumers are getting paid by the aggregators.

Niesten and Alkemade [63], claim that unfortunately, the proper business model of demand response is not provided by the existing literature. However, articles discuss how the providers of demand response services are creating and capturing value which is summarized in Table 5 .

Over 500 consumers from four European countries who participated in the survey mentioned that they are pleased to follow smart grid signals and to get an opportunity to regulate their electricity usage [136]. Therefore, the end-users can reduce their consumption level and pay less for electricity. In December 2011, 69 Japanese households joined an inquiry of demand response service, which had a 
Table 5. Values through smart grid services for different actors [63].

\begin{tabular}{|c|c|c|c|}
\hline $\begin{array}{l}\text { Services Provided } \\
\text { by Smart Grid }\end{array}$ & Values for Consumers & Values for System Operators & $\begin{array}{l}\text { Values for Service } \\
\text { Providers/Aggregators }\end{array}$ \\
\hline $\begin{array}{l}\text { Demand } \\
\text { Response } \\
\text { Services }\end{array}$ & $\begin{array}{ll}\text { - } & \text { Electricity bills will reduce } \\
\text { - } & \text { Consumption of electricity } \\
& \text { will reduce } \\
\text { - } & \text { Electricity quality will improve } \\
\text { - } & \text { More control over } \\
& \text { electricity usage } \\
- & \text { Blackouts will decrease } \\
- & \text { Customers will have multiple } \\
& \text { options for selecting different } \\
& \text { electricity packages }\end{array}$ & 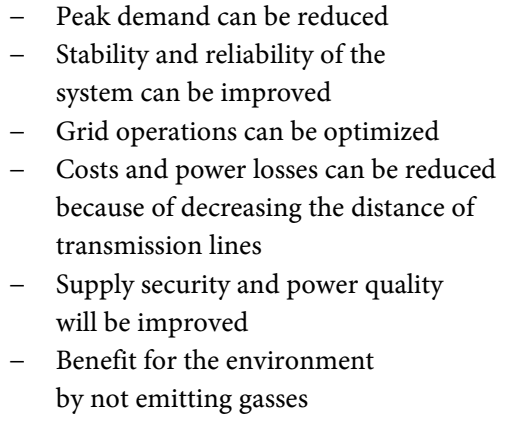 & $\begin{array}{l}\text { - Investment in a power plant } \\
\text { can be reduced by } \\
\text { decreasing peak demand } \\
\text { - Income can be increased by } \\
\text { offering additional services } \\
\text { - } \quad \text { For energy retailers, } \\
\text { sourcing cost can be reduced }\end{array}$ \\
\hline
\end{tabular}

token-based reward system. The usage of electricity declined by $30 \%$ [20]. Observation showed that from $10 \%$ to $15 \%$ of electricity payments can be saved by households by usage regulation based on time-of-use tariffs [120]. Due to diminished peak demand from demand response, the operators of the system can reduce service providing costs, have a more secure system, and minimize the risks of system overload. According to research, in the USA $\$ 2.7$ billion power generation costs can be saved yearly through a $5 \%$ reduction of the peak demand [67]. DR aggregators can get profits from providing demand response services to operators of the system. According to Warren [137] the UK can get yearly 66,000 pounds revenue by using $3 \mathrm{MW}$ demand-side participation. Dave et al. [134] stated that a DR aggregator could get 1800 pounds revenue per household over 20 years. The essential part for DR aggregators is the installation of communication infrastructure because it is the foundation of the business model. After the installation, just system control and data management require additional costs [134]. There is no need to spend more for higher generation capacity since demand response allows power generation with lower costs [84]. Value capturing through demand response is possible if the DR aggregator takes the role of the retailer as well, which will reduce power purchasing costs [67]. It is mentioned by Goebel [120] that because reselling the electricity is the core business of retailers, they will be delighted to decrease purchasing costs as much as possible. Stoll et al. [132] did research to determine how shifting 1-kilowatt-hour from an on-peak to an off-peak hour by using the time-of-use tariffs, and real-time pricing will affect the electricity markets of Sweden and Canada (Ontario). As a result, time-of-use and real-time tariffs are decreasing purchasing costs sufficiently in Ontario.

\section{Discussion}

This discussion drives us to the conclusion of the necessity for energy providing firms to adopt smart grid technology and accordingly innovate their business models for commercializing new energy distribution systems along with offering new services to energy consumers in terms of capturing value and sustaining the 
digitalized energy market.

The $21^{\text {st }}$ century is establishing a new era of energy sources by attempting to switch energy production from fossil fuels to renewable sources. This changeover is reinforced by several aspects, such as fossil fuel delivery restrictions, costs, environmental safety (especially changes in climate and temperature) and evolution in technology [25]. Timmons et al. [24] pointed out that costs of renewable energy will be reduced more, while costs of fossil fuels are expected to grow. Furthermore, Bhatti and Danilovic [1] stated that in decentralized and localized systems, electricity is distributed to specific geographic areas. Therefore, if electricity is generated in the same place where consumers live, the distribution and transmission costs will be reduced. Meanwhile, in a centralized system of power generation, there is a long distance between consumers and generation places which makes the distribution costly. Moreover, decentralized and localized systems can be integrated with renewable energy sources which provide clean energy whereas centralized systems produce electricity with the use of fossil fuels and emit greenhouse gases which are harmful to the environment. Similarly, Feisst et al. [34] repeated that traditional grids emit $25 \%$ of global greenhouse gases. Digitalized technologies are not viable with the traditional grid, as it cannot be integrated with solar, wind energy, low-inertia sources of electricity generation and distributed generation system [33]. Therefore, Banerjee et al. [35] claimed that smart grid is suitable for renewable energy and distribution system since it contains contemporary technologies for electricity generation and supply. Smartgrid can automatically identify system conflicts and fix them, by providing reliable protection from external dangers and cyber-attacks. Thus, economic tendencies are shifting towards renewable sources, even without proper government regulations.

Shomali and Pinkse [21] stated that the smart grid is the future energy technology, and it has full potential to disrupt the energy providing firms, as it can change the entire process and structure of the energy market. Furthermore, Richter [58] claimed that the term "disruptive technology" in the energy industry is mostly associated with solar photovoltaic, wind turbines and energy storage technologies. These technologies have an immense impact on centralized power generation systems whereas, on the other hand, the same technologies support decentralized and localized power generation systems which give open access to households to generate power for their home usage.

Zhou et al. [60] stated that smart grid is an emerging technology which is transforming the whole energy industry. It can easily be integrated with different energy objects; such as; electric vehicles, natural gas, energy saving devices, and renewable energy sources. However, Niesten and Alkemade [63] and Welsch et al. [64] argued that several scholars have claimed that no technical or functional smart grid exists yet but claimed that the martgrid would make its emergence soon. Therefore, Tayal [68] stated that electric firms should not avoid disruptive challenges for a long time. Electric utilities should consider the effects of disruptive threats in other industries such as policy changes, technological innovation, 
and the preferences of customers as well. Energy providing firms should be willing to change their business models along with accepting new technologies. Moreover, Faucheux and Nicolaï [70] stated, that it is necessary for the energy providing firms to develop a new or redesigned business model. Thus, they can create and capture value on a larger scale by providing smart grid services to customers whereas Johnson and Suskewicz [71] stated that for the complete change of the energy industry, it is crucial to develop a new business model concurrently with the rapid shift in technology.

Osterwalder [13] stated that business models are the instruments for firms to identify their technical challenges and clarify the capabilities needed to be achieved. Chesbrough [138] stated that business model innovation is a process of trials rather than planning. Companies try to change their business models based on experience and mistakes. It is about trying not predicting. Sosna et al. [17] claimed that business model innovation is the development of ways to create, deliver and capture value. Mardookhy et al. [79], stated that recent surveys show that $82 \%$ of respondents are dissatisfied with their present electricity system as they reported that electricity prices are too high and new mechanisms should be integrated to measure electricity usage. Geelen et al. [80] stated that by adopting smart grid technology energy, providing firms offer more value to the customers regarding more control over electricity consumption. However, Marino et al. [81] argued that the features of smart grid will show the usage of data to the consumers which could decrease the profits of electric companies.

Thus, if companies want to integrate a smart grid system, they need to change their business model as well as the values that they are creating for consumers. Schiavo et al. [84] stated that electric companies could deliver new value to consumers through constructing sufficient stations for electric vehicle recharging. Zio and Aven [86] stated that energy firms add value by providing better and uninterrupted power supply. Furthermore, Clastres [10] pointed out that smart grids' advanced mechanism can show electrical system problems immediately, which allows companies to fix technical issues through switching between diverse power delivery sources. Boait et al. [89] claimed that demand response and transparent data are significant components of the new value created by electric firms. Similarly, Fox-Penner [105] stated that companies would change their value delivery by adopting smart grid. Smart grid allows retaining data from gird components and distributed energy sources. Piccoli and Pigni [107] stated that with the help of big data energy providing firms can understand the requirements of the customers which enables them to deliver better values according to the demand. Subsequently, Adam and Wintersteller [113] stated that smart grid would open up new opportunities and needs by which firms can utilize and deliver new value to their consumers, and in return, they can capture value. Energy providing firms can sell data to the energy retailers which they can use to build energy equipment for the consumers according to their need. Geelen et al. [80] stated that value could be captured by establishing a partnership with appliance producers. These producers can sell energy efficient kitchen or home-based in- 
struments to the consumers. Giordano and Fulli [92] claimed that money could be saved on extra staff by installing remote controls over the grid which themselves can detect and fix the problems rather than physically going and repairing it. Poudineh and Jamasb [111] repeated that transmission cost could be saved by adopting a smart grid system as it supports a decentralized power generation system which is close to the end users.

\section{Conclusions}

This paper addressed the disruption of advancement in the technology associated with the introduction of smart grid systems and the creation of localized energy production and localized energy consumption in the energy industry and its impacts on the business models of energy providing firms. This study has revealed that firms that adopted the changes in technology and rapidly responded in the market by changing their business models, were successful whereas firms that were reluctant in changing their business models, even though they adopted the changes in technology, died.

Similarly, smart grid is an emerging digitilized technology which has full capability to revolutionize the energy industry. Research indicates that adopting smart grid would be a wise decision as it enables energy firms to create and deliver value to meet the future demand of consumers. Moreover, it is necessary for the energy providing firms to innovate their business models for commercializing every feature of a smart grid through which firms can create value for the energy consumers and can capture value regarding more profit. This paper highlights three services such as; integration of renewable energy with smart grid, electric vehicle services, and demand response services which will enable energy firms to create value for their consumers and gain profit. The cost of energy for consumers can be reduced, and for the firms, profits can be increased by integrating renewable energy sources with smart grid. Demand response services will help consumers to have more control over usage which will help to reduce the usage of electricity and can fulfill the rising demand for electricity in other regions. More vehicles on electricity mean less carbon emission in the environment and of course income for energy providers regarding charging electric vehicle batteries.

However, it is still arduous to figure out exact costs and profits of smart grid integration, because currently the smart grid technology is in the development stage and has not been fully introduced to electricity market yet. Thus, possible benefits and losses are concerned with the specific country's situation because some countries' governments are in favor of new technology integration and are willing to give strong support, while some governments do not have resources to support or are uncertain about smart grid's benefits.

\section{Conflicts of Interest}

The authors declare no conflicts of interest regarding the publication of this paper. 


\section{References}

[1] Bhatti, H.J. and Danilovic, M. (2018) Making the World More Sustainable: Enabling Localized Energy Generation and Distribution on Decentralized Smart Grid Systems. World Journal of Engineering and Technology, 6, 350-382.

https://doi.org/10.4236/wjet.2018.62022

[2] Grace, W. (2014) Exploring the Death Spiral-A System Dynamics Model of the South West Interconnected System. AUDRC Laboratory.

[3] Allen, M.R., et al. (2009) Warming Caused by Cumulative Carbon Emissions towards the Trillionth Tonne. Nature, 458, 1163-1166. https://doi.org/10.1038/nature08019

[4] McDonough, W. and Braungart, M. (2002) Remaking the Way We Make Things: Cradle to Cradle. ISBN, 1224942886, North Point Press, New York, 104.

[5] Christensen, C.M. (1997) The Innovator's Dilemma: The Revolutionary Book That Will Change the Way You Do Business (Collins Business Essentials).

[6] Bower, J.L. and Christensen, C.M. (1996) Disruptive Technologies: Catching the Wave. The Journal of Product Innovation Management, 1, 75-76.

[7] Erlinghagen, S. and Markard, J. (2012) Smart Grids and the Transformation of the Electricity Sector: ICT Firms as Potential Catalysts for Sectoral Change. Energy Policy, 51, 895-906. https://doi.org/10.1016/j.enpol.2012.09.045

[8] Battaglini, A., et al. (2009) Development of SuperSmart Grids for a More Efficient Utilisation of Electricity from Renewable Sources. Journal of Cleaner Production, 17, 911-918. https://doi.org/10.1016/j.jclepro.2009.02.006

[9] Inage, S.-I. (2010) Modelling Load Shifting Using Electric Vehicles in a Smart Grid Environment.

[10] Clastres, C. (2011) Smart Grids: Another Step towards Competition, Energy Security and Climate Change Objectives. Energy Policy, 39, 5399-5408. https://doi.org/10.1016/j.enpol.2011.05.024

[11] Kind (2013) Disruptive Challenges: Financial Implications and Strategic Responses to a Changing Retail Electric Business. Edison Electric Institute.

[12] Frantzis, L., et al. (2008) Photovoltaics Business Models. National Renewable Energy Laboratory (NREL), Golden, CO. https://doi.org/10.2172/924651

[13] Osterwalder, A. (2004) The Business Model Ontology: A Proposition in a Design Science Approach.

[14] Teece, D.J. (2010) Business Models, Business Strategy and Innovation. Long Range Planning, 43, 172-194. https://doi.org/10.1016/j.lr2009.07.003

[15] DaSilva, C.M. and Trkman, P. (2014) Business Model: What It Is and What It Is Not. Long Range Planning, 47, 379-389.

[16] Baden-Fuller, C. and Haefliger, S. (2013) Business Models and Technological Innovation. Long Range Planning, 46, 419-426. https://doi.org/10.1016/j.lr2013.08.023

[17] Sosna, M., Trevinyo-Rodríguez, R.N. and Velamuri, S.R. (2010) Business Model Innovation through Trial-and-Error Learning: The Naturhouse Case. Long Range Planning, 43, 383-407. https://doi.org/10.1016/j.lr2010.02.003

[18] Christensen, C.M. and Bower, J.L. (1996) Customer Power, Strategic Investment, and the Failure of Leading Firms. Strategic Management Journal, 17, 197-218. https://doi.org/10.1002/(SICI)1097-0266(199603)17:3<197::AID-SMJ804>3.0.CO;2-U

[19] Bocken, N., et al. (2014) A Literature and Practice Review to Develop Sustainable Business Model Archetypes. Journal of Cleaner Production, 65, 42-56. 
https://doi.org/10.1016/j.jclepro.2013.11.039

[20] Mah, D.N.-Y., et al. (2013) The Role of the State in Sustainable Energy Transitions: A Case Study of Large Smart Grid Demonstration Projects in Japan. Energy Policy, 63, 726-737. https://doi.org/10.1016/j.enpol.2013.07.106

[21] Shomali, A. and Pinkse, J. (2016) The Consequences of Smart Grids for the Business Model of Electricity Firms. Journal of Cleaner Production, 112, 3830-3841. https://doi.org/10.1016/j.jclepro.2015.07.078

[22] Amit, R. and Zott, C. (2001) Value Creation in E-Business. Strategic Management Journal, 22, 493-520. https://doi.org/10.1002/smj.187

[23] IEA (2017) World Energy Outlook 2017. Organisation for Economic Co-Operation and Development, OECD.

[24] Timmons, D., Harris, J.M. and Roach, B. (2014) The Economics of Renewable Energy. Global Development and Environment Institute, Tufts University, 52.

[25] Agency, I.E. (2013) Key World Energy Statistics. International Energy Agency.

[26] IEA (2007) Renewables in Global Energy Supply. International Energy Agency and Organization for Economic Cooperation and Development.

[27] Feldman, D., Barbose, G., Margolis, R., Wiser, R., Darghouth, N. and Goodrich, A. (2012) Photovoltaic (PV) Pricing Trends: Historical, Recent, and Near-Term Projections (No. LBNL-6019E). Lawrence Berkeley National Lab. (LBNL), Berkeley, CA.

[28] Jonkman, J.M. and Buhl Jr., M. (2005) FAST User's Guide, National Renewable Energy Laboratory. No. NREL/EL-500-38230, Golden, CO.

[29] Momoh, J.A., Meliopoulos, S. and Saint, R. (2012) Centralized and Distributed Generated Power Systems-A Comparison Approach. Future Grid Initiative White Paper, 1-10.

[30] Basso, T.S. and DeBlasio, R. (2004) IEEE 1547 Series of Standards: Interconnection Issues. IEEE Transactions on Power Electronics, 19, 1159-1162.

https://doi.org/10.1109/TPEL.2004.834000

[31] Hadjsaid, N., Canard, J.-F. and Dumas, F. (1999) Dispersed Generation Impact on Distribution Networks. IEEE Computer Applications in Power, 12, 22-28. https://doi.org/10.1109/67.755642

[32] Zame, K.K., et al. (2017) Smart Grid and Energy Storage: Policy Recommendations. Renewable and Sustainable Energy Reviews, 82, 1646-1654.

[33] Hossain, M.R., Oo, A.M. and Ali, A.S. (2013) Smart Grid, in Smart Grids. Springer, Berlin, 23-44.

[34] Feisst, C., Schlesinger, D. and Frye, W. (2008) Smart Grid: The Role of Electricity Infrastructure in Reducing Greenhouse Gas Emissions. Cisco Internet Business Solution Group (IBSG), San Jose, CA.

[35] Banerjee, S., et al. (2011) Report on the First Quadrennial Technology Review. US Department of Energy.

[36] Papavasiliou, A. and Oren, S.S. (2014) Large-Scale Integration of Deferrable Demand and Renewable Energy Sources. IEEE Transactions on Power Systems, 29, 489-499. https://doi.org/10.1109/TPWRS.2013.2238644

[37] Atteya, I.I., Ashour, H.A., Fahmi, N. and Strickland, D. (2016) Distribution Network Reconfiguration in Smart Grid System Using Modified Particle Swarm Optimization. 2016 IEEE International Conference on Renewable Energy Research and Applications (ICRERA), Birmingham, 20-23 November 2016, 305-313. 
[38] Kuhn, T.S. (2012) The Structure of Scientific Revolutions. University of Chicago Press, Chicago. https://doi.org/10.7208/chicago/9780226458144.001.0001

[39] Pentland, A. (2015) Social Physics: How Social Networks Can Make Us Smarter. NY Penguin Books, New York.

[40] Qiu, L. (2017) False ISIS Connections, Nonexistent Victims and Other Misinformation in the Wake of Las Vegas Shooting. The New York Times.

https://www.nytimes.com/2017/10/02/us/politics/viral-claims-and-rumors-in-the-la s-vegas-shooting.html

[41] Beinhocker, E.D. (2006) The Origin of Wealth: Evolution, Complexity, and the Radical Remaking of Economics. Harvard Business Press, Harvard.

[42] Gonzalez, A. (2014) Single-Serve Coffee Revolution Brews Industry Change. http://seattletimes.com/html/businesstechnology/2022910303_singleservexml.html

[43] Hamblin, J. (2015) A Brewing Problem. The Atlantic, 2.

[44] Christensen, C.M., M.E. Raynor, and McDonald, R. (2015) What Is Disruptive Innovation. Harvard Business Review, 93, 44-53.

[45] Enerquire (2017) Disruptive Innovation in the Energy Sector-Definition \& Application to Renewables.

https://www.enerquire.com/blog/disruptive-innovations-in-the-energy-sector-defin ition-application

[46] Brunekreeft, G., Buchmann, M. and Meyer, R. (2016) The Rise of Third Parties and the Fall of Incumbents Driven by Large-Scale Integration of Renewable Energies: The Case of Germany. Energy Journal, 37.

[47] Cuthbertson, R., Furseth, P.I. and Ezell, S.J. (2015) Kodak and Xerox: How High Risk Aversion Kills Companies, in Innovating in a Service-Driven Economy. Springer, Berlin, 166-179.

[48] Haftor, D.M. (2015) Some Heuristics for Digital Business Model Configuration. In: Persson, A. and Stirna, J., Eds., Advanced Information Systems Engineering Workshops. CAiSE 2015. Lecture Notes in Business Information Processing, Vol. 215, Springer, Cham, 123-130.

[49] Baron, D.P. (1997) Integrated Strategy and International Trade Disputes: The Kodak-Fujifilm Case. Journal of Economics \& Management Strategy, 6, 291-346. https://doi.org/10.1162/105864097567110

[50] Liu, J.-H. and Meng, Z. (2017) Innovation Model Analysis of New Energy Vehicles: Taking Toyota, Tesla and BYD as an Example. Procedia Engineering, 174, 965-972. https://doi.org/10.1016/j.proeng.2017.01.248

[51] Wilson, C. (2017) Disruptive Low-Carbon Innovations. Energy Research \& Social Science, 37, 216-223.

[52] Fei, L. and Xi, L. (2004) Defining Competitive Positioning Strategy: A Comprehensive Model. Nankai Business Review, 5, 7.

[53] Lambert, C. (2014) Disruptive Genius. Harvard Magazine, 116, 38-43.

[54] Mathew, R.V. (2015) Tesla's Not as Disruptive as You Might Think. Harvard Business Review, 93, 16.

[55] Rogers, E. (2003) Difussion of Innovations. Free Press, New York.

[56] Raouf, F. (2013) The Innovation Problem: Nokia’s Fall From Grace. http://www.businessinsider.com/the-innovation-problem-nokias-fall-from-grace-20 $\underline{13-1}$

[57] Wilkinson, D. (2016) Why Nokia Died a Sudden Death and Why It Matters to Your 
Organisation. https://www.oxford-review.com/survive-disruptive-innovation/

[58] Richter, M. (2013) German Utilities and Distributed PV: How to Overcome Barriers to Business Model Innovation. Renewable Energy, 55, 456-466. https://doi.org/10.1016/j.renene.2012.12.052

[59] Cardenas, J.A., et al. (2014) A Literature Survey on Smart Grid Distribution: An Analytical Approach. Journal of Cleaner Production, 65, 202-216. https://doi.org/10.1016/j.jclepro.2013.09.019

[60] Zhou, K., Yang, S. and Shao, Z. (2016) Energy Internet: The Business Perspective. Applied Energy, 178, 212-222. https://doi.org/10.1016/j.apenergy.2016.06.052

[61] Yigit, M., Gungor, V.C. and Baktir, S. (2014) Cloud Computing for Smart Grid Applications. Computer Networks, 70, 312-329. https://doi.org/10.1016/j.comnet.2014.06.007

[62] Zhou, K. and Yang, S. (2016) Understanding Household Energy Consumption Behavior: The Contribution of Energy Big Data Analytics. Renewable and Sustainable Energy Reviews, 56, 810-819. https://doi.org/10.1016/j.rser.2015.12.001

[63] Niesten, E. and Alkemade, F. (2016) How Is Value Created and Captured in Smart Grids? A Review of The literature and an Analysis of Pilot Projects. Renewable and Sustainable Energy Reviews, 53, 629-638. https://doi.org/10.1016/j.rser.2015.08.069

[64] Welsch, M., et al. (2013) Smart and Just Grids for Sub-Saharan Africa: Exploring Options. Renewable and Sustainable Energy Reviews, 20, 336-352. https://doi.org/10.1016/j.rser.2012.11.004

[65] Colak, I., et al. (2014) Smart Grid Opportunities and Applications in Turkey. Renewable and Sustainable Energy Reviews, 33, 344-352. https://doi.org/10.1016/j.rser.2014.02.009

[66] Siano, P. (2014) Demand Response and Smart Grids-A Survey. Renewable and Sustainable Energy Reviews, 30, 461-478. https://doi.org/10.1016/j.rser.2013.10.022

[67] Shen, B., et al. (2014) The Role of Regulatory Reforms, Market Changes, and Technology Development to Make Demand Response a Viable Resource in Meeting Energy Challenges. Applied Energy, 130, 814-823. https://doi.org/10.1016/j.apenergy.2013.12.069

[68] Tayal, D. (2016) Disruptive Forces on the Electricity Industry: A Changing Landscape for Utilities. The Electricity Journal, 29, 13-17. https://doi.org/10.1016/j.tej.2016.08.004

[69] Nahan, M. (2015) Opening Address: Energy WA Conference. Vol. 26, Perth, WA.

[70] Faucheux, S. and Nicolaï, I. (2011) IT for Green and Green IT: A Proposed Typology of Eco-Innovation. Ecological Economics, 70, 2020-2027. https://doi.org/10.1016/j.ecolecon.2011.05.019

[71] Johnson, M.W. and Suskewicz, J. (2009) How to Jump-Start the Clean Economy. Vol. 87, Harvard Business School Publishing, Brighton.

[72] Magretta, J. (2002) Why Business Models Matter. Harvard Business Review, 80, 86-92.

[73] Zott, C., Amit, R. and Massa, L. (2011) The Business Model: Recent Developments and Future Research. Journal of Management, 37, 1019-1042. https://doi.org/10.1177/0149206311406265

[74] Markovic, D.S., et al. (2013) Smart Power Grid and Cloud Computing. Renewable and Sustainable Energy Reviews, 24, 566-577. https://doi.org/10.1016/j.rser.2013.03.068 
[75] Chesbrough, H. and Rosenbloom, R.S. (2002) The Role of the Business Model in Capturing Value from Innovation: Evidence from Xerox Corporation's Technology Spin-Off Companies. Industrial and Corporate Change, 11, 529-555. https://doi.org/10.1093/icc/11.3.529

[76] Baden-Fuller, C. and Morgan, M.S. (2010) Business Models as MODELS. Long Range Planning, 43, 156-171. https://doi.org/10.1016/j.lrp.2010.02.005

[77] Johnson, M.W. (2010) Seizing the White Space: Business Model Innovation for Growth and Renewal. Harvard Business Press, Brighton.

[78] Osterwalder, A., Pigneur, Y. and Tucci, C.L. (2005) Clarifying Business Models: Origins, Present, and Future of the Concept. Communications of the Association for Information Systems, 16, Article No. 1.

[79] Mardookhy, M., et al. (2014) A Study of Energy Efficiency in Residential Buildings in Knoxville, Tennessee. Journal of Cleaner Production, 85, 241-249. https://doi.org/10.1016/j.jclepro.2013.09.025

[80] Geelen, D., Reinders, A. and Keyson, D. (2013) Empowering the End-User in Smart Grids: Recommendations for the Design of Products and Services. Energy Policy, 61, 151-161. https://doi.org/10.1016/j.enpol.2013.05.107

[81] Marino, A., et al. (2011) A Snapshot of the European Energy Service Market in 2010 and Policy Recommendations to Foster a Further Market Development. Energy Policy, 39, 6190-6198. https://doi.org/10.1016/j.enpol.2011.07.019

[82] Mogel, W.A. (2010) Smart Power: Climate Change, the Smart Grid and the Future of Electric Utilities. Energy Law Journal, 31, 183.

[83] Carillo-Aparicio, S., Heredia-Larrubia, J.R. and Perez-Hidalgo, F. (2013) SmartCity Málaga, a Real-Living Lab and Its Adaptation to Electric Vehicles in Cities. Energy Policy, 62, 774-779. https://doi.org/10.1016/j.enpol.2013.07.125

[84] Schiavo, L.L., et al. (2013) Changing the Regulation for Regulating the Change: Innovation-Driven Regulatory Developments for Smart Grids, Smart Metering and E-Mobility in Italy. Energy Policy, 57, 506-517. https://doi.org/10.1016/j.enpol.2013.02.022

[85] Sierzchula, W., et al. (2014) The Influence of Financial Incentives and Other Socio-Economic Factors on Electric Vehicle Adoption. Energy Policy, 68, 183-194. https://doi.org/10.1016/j.enpol.2014.01.043

[86] Zio, E. and Aven, T. (2011) Uncertainties in Smart Grids Behavior and Modeling: What Are the Risks and Vulnerabilities? How to Analyze Them? Energy Policy, 39, 6308-6320. https://doi.org/10.1016/j.enpol.2011.07.030

[87] Jamasb, T. and Pollitt, M. (2005) Electricity Market Reform in the European Union: Review of Progress toward Liberalization \& Integration. The Energy Journal, 26, 11-41. https://doi.org/10.5547/ISSN0195-6574-EJ-Vol26-NoSI-2

[88] Faruqui, A., Harris, D. and Hledik, R. (2010) Unlocking the €53 Billion Savings from Smart Meters in the EU: How Increasing the Adoption of Dynamic Tariffs Could Make or Break the EU's Smart Grid Investment. Energy Policy, 38, 6222-6231. https://doi.org/10.1016/j.enpol.2010.06.010

[89] Boait, P.J., et al. (2013) Managing Complexity in the Smart Grid through a New Approach to Demand Response. Emergence: Complexity and Organization, 15, 23.

[90] Gangale, F., Mengolini, A. and Onyeji, I. (2013) Consumer Engagement: An Insight from Smart Grid Projects in Europe. Energy Policy, 60, 621-628. https://doi.org/10.1016/j.enpol.2013.05.031

[91] Gans, W., Alberini, A. and Longo, A. (2013) Smart Meter Devices and the Effect of 
Feedback on Residential Electricity Consumption: Evidence from a Natural Experiment in Northern Ireland. Energy Economics, 36, 729-743. https://doi.org/10.1016/j.eneco.2012.11.022

[92] Giordano, V. and Fulli, G. (2012) A Business Case for Smart Grid Technologies: A Systemic Perspective. Energy Policy, 40, 252-259.

[93] He, X., et al. (2013) How to Engage Consumers in Demand Response: A Contract Perspective. Utilities Policy, 27, 108-122. https://doi.org/10.1016/j.jup.2013.10.001

[94] Al-Saleh, Y. and Mahroum, S. (2015) A Critical Review of the Interplay between Policy Instruments and Business Models: Greening the Built Environment a Case in Point. Journal of Cleaner Production, 109, 260-270. https://doi.org/10.1016/j.jclepro.2014.08.042

[95] Richter, M. (2013) Business Model Innovation for Sustainable Energy: German Utilities and Renewable Energy. Energy Policy, 62, 1226-1237. https://doi.org/10.1016/j.enpol.2013.05.038

[96] Smil, V. (2010) Energy Transitions: History, Requirements, Prospects. ABC-CLIO, Santa Barbara.

[97] Lehtovaara, M., et al. (2012) Commercializing Emerging Renewable Energy: A Case Study. International Journal of Engineering Business Management, 4, 44. https://doi.org/10.5772/54707

[98] Lynas, M. (2008) Six Degrees: Our Future on a Hotter Planet. National Geographic Books.

http://www.trans-techresearch.net/wp-content/uploads/2015/03/LRQ-1.01.pdf\#pag $\underline{\mathrm{e}=69}$

[99] Weijermars, R., et al. (2012) Review of Models and Actors in Energy Mix Optimization-Can Leader Visions and Decisions Align with Optimum Model Strategies for Our Future Energy Systems? Energy Strategy Reviews, 1, 5-18. https://doi.org/10.1016/j.esr.2011.10.001

[100] Gore, A. (2009) Our Choice: A Plan to Solve the Climate Crisis. Rodale Books. Rodale, Emmaus, PA.

[101] Council, G.W.E. (2008) Global Wind Energy Outlook 2008. Vol. 19, GWEC, Brussels.

[102] Lehtovaara, M., et al. (2011) Product Modularity Influences on Firm Performance: Evidence from Bioenergy Technology. Mechanika (Kaunas), 17, 562-569.

[103] Wüstenhagen, R. and Bilharz, M. (2006) Green Energy Market Development in Germany: Effective Public Policy and Emerging Customer Demand. Energy policy, 34, 1681-1696. https://doi.org/10.1016/j.enpol.2004.07.013

[104] Cappers, P., et al. (2012) An Assessment of the Role Mass Market Demand Response Could Play in Contributing to the Management of Variable Generation Integration Issues. Energy Policy, 48, 420-429. https://doi.org/10.1016/j.enpol.2012.05.040

[105] Fox-Penner, P. (2009) Fix Utilities before They Need a Rescue. Harvard Business School Publishing Corporation, Watertown, MA.

[106] Valocchi, M., Juliano, J. and Schurr, A. (2014) Switching Perspectives: Creating New Business Models for a Changing World of Energy, in Smart Grid Applications and Developments. Springer, Berlin, 165-182.

[107] Piccoli, G. and Pigni, F. (2013) Harvesting External Data: The Potential of Digital Data Streams. MIS Quarterly Executive, 12, 143-154.

[108] Weiller, C.M. and Pollitt, M.G. (2016) Platform Markets and Energy Services. Smart 
Grid Handbook, 1-23.

[109] Eisenmann, T., Parker, G. and Van Alstyne, M.W. (2006) Strategies for Two-Sided Markets. Harvard Business Review, 84, 92.

[110] Lehr, R.L. (2013) New Utility Business Models: Utility and Regulatory Models for the Modern Era. The Electricity Journal, 26, 35-53.

[111] Poudineh, R. and Jamasb, T. (2014) Distributed Generation, Storage, Demand Response and Energy Efficiency as Alternatives to Grid Capacity Enhancement. Energy Policy, 67, 222-231. https://doi.org/10.1016/j.enpol.2013.11.073

[112] Covrig, C.F., et al. (2014) Smart Grid Projects Outlook 2014. JRC Science and Policy Reports.

[113] Tao, H.Y.S., Bahabry, A. and Cloutier, R. (2015) Customer Centricity in the Smart Grid Model. Procedia Computer Science, 44, 115-124.

https://doi.org/10.1016/j.procs.2015.03.042

[114] Barley, S. (2011) In Search of a Black Swan. Nature Climate Change, 1, 76-79. https://doi.org/10.1038/nclimate1091

[115] Richter, M. (2012) Utilities' Business Models for Renewable Energy: A Review. Renewable and Sustainable Energy Reviews, 16, 2483-2493. https://doi.org/10.1016/j.rser.2012.01.072

[116] Gordijn, J. and Akkermans, H. (2007) Business Models for Distributed Generation in a Liberalized Market Environment. Electric Power Systems Research, 77, 1178-1188. https://doi.org/10.1016/j.epsr.2006.08.008

[117] Eberle, U., Müller, B. and Von Helmolt, R. (2012) Fuel Cell Electric Vehicles and Hydrogen Infrastructure: Status 2012. Energy \& Environmental Science, 5, 8780-8798. https://doi.org/10.1039/c2ee22596d

[118] Richardson, D.B. (2013) Electric Vehicles and the Electric Grid: A Review of Modeling Approaches, Impacts, and Renewable Energy Integration. Renewable and Sustainable Energy Reviews, 19, 247-254. https://doi.org/10.1016/j.rser.2012.11.042

[119] Kempton, W. and Tomić, J. (2005) Vehicle-to-Grid Power Implementation: From Stabilizing the Grid to Supporting Large-Scale Renewable Energy. Journal of Power Sources, 144, 280-294. https://doi.org/10.1016/j.jpowsour.2004.12.022

[120] Goebel, C. (2013) On the Business Value of ICT-Controlled Plug-In Electric Vehicle Charging in California. Energy Policy, 53, 1-10. https://doi.org/10.1016/j.enpol.2012.06.053

[121] Palizban, O., Kauhaniemi, K. and Guerrero, J.M. (2014) Microgrids in Active Network Management-Part I: Hierarchical Control, Energy Storage, Virtual Power Plants, and Market Participation. Renewable and Sustainable Energy Reviews, 36, 428-439. https://doi.org/10.1016/j.rser.2014.01.016

[122] Schleicher-Tappeser, R. (2012) How Renewables Will Change Electricity Markets in the Next Five Years. Energy Policy, 48, 64-75.

https://doi.org/10.1016/j.enpol.2012.04.042

[123] Armstrong, M., et al. (2013) Optimal Recharging Strategy for Battery-Switch Stations for Electric Vehicles in France. Energy Policy, 60, 569-582. https://doi.org/10.1016/j.enpol.2013.05.089

[124] Barkenbus, J. (2009) Our Electric Automotive Future: $\mathrm{CO}_{2}$ Savings through a Disruptive Technology. Policy and Society, 27, 399-410. https://doi.org/10.1016/j.polsoc.2009.01.005

[125] Loisel, R., Pasaoglu, G. and Thiel, C. (2014) Large-Scale Deployment of Electric Vehicles in Germany by 2030: An Analysis of Grid-to-Vehicle and Vehicle-to-Grid 
Concepts. Energy Policy, 65, 432-443. https://doi.org/10.1016/j.enpol.2013.10.029

[126] Guille, C. and Gross, G. (2009) A Conceptual Framework for the Vehicle-to-Grid ( $V 2$ G) Implementation. Energy Policy, 37, 4379-4390.

https://doi.org/10.1016/j.enpol.2009.05.053

[127] Jargstorf, J. and Wickert, M. (2013) Offer of Secondary Reserve with a Pool of Electric Vehicles on the German Market. Energy Policy, 62, 185-195. https://doi.org/10.1016/j.enpol.2013.06.088

[128] Hill, D.M., Agarwal, A.S. and Ayello, F. (2012) Fleet Operator Risks for Using Fleets for V2G Regulation. Energy Policy, 41, 221-231. https://doi.org/10.1016/j.enpol.2011.10.040

[129] Gerpott, T.J. and Paukert, M. (2013) Determinants of Willingness to Pay for Smart Meters: An Empirical Analysis of Household Customers in Germany. Energy Policy, 61, 483-495.https://doi.org/10.1016/j.enpol.2013.06.012

[130] San Román, T.G., et al. (2011) Regulatory Framework and Business Models for Charging Plug-In Electric Vehicles: Infrastructure, Agents, and Commercial Relationships. Energy Policy, 39, 6360-6375. https://doi.org/10.1016/j.enpol.2011.07.037

[131] Wissner, M. (2011) The Smart Grid-A Saucerful of Secrets? Applied Energy, 88, 2509-2518. https://doi.org/10.1016/j.apenergy.2011.01.042

[132] Stoll, P., Brandt, N. and Nordström, L. (2014) Including Dynamic $\mathrm{CO}_{2}$ Intensity with Demand Response. Energy Policy, 65, 490-500.

https://doi.org/10.1016/j.enpol.2013.10.044

[133] Verbong, G.P., Beemsterboer, S. and Sengers, F. (2013) Smart Grids or Smart Users? Involving Users in Developing a Low Carbon Electricity Economy. Energy Policy, 52, 117-125. https://doi.org/10.1016/j.enpol.2012.05.003

[134] Dave, S., Sooriyabandara, M. and Yearworth, M. (2013) System Behaviour Modelling for Demand Response Provision in a Smart Grid. Energy Policy, 61, 172-181. https://doi.org/10.1016/j.enpol.2013.05.098

[135] Cappers, P., et al. (2013) An Assessment of Market and Policy Barriers for Demand Response Providing Ancillary Services in US Electricity Markets. Energy Policy, 62, 1031-1039. https://doi.org/10.1016/j.enpol.2013.08.003

[136] Curtius, H.C., Künzel, K. and Loock, M. (2012) Generic Customer Segments and Business Models for Smart Grids. der markt, 51, 63-74. https://doi.org/10.1007/s12642-012-0076-0

[137] Warren, P. (2014) A Review of Demand-Side Management Policy in the UK. Renewable and Sustainable Energy Reviews, 29, 941-951. https://doi.org/10.1016/j.rser.2013.09.009

[138] Chesbrough, H. (2010) Business Model Innovation: Opportunities and Barriers. Long Range Planning, 43, 354-363. https://doi.org/10.1016/j.lrp.2009.07.010 